\title{
GIS-Based Modeling for Selection of Dam Sites in the Kurdistan Region, Iraq
}

\author{
Arsalan Ahmed Othman ${ }^{1, *(\mathbb{D}}$, Ahmed F. Al-Maamar ${ }^{2}$, Diary Ali Mohammed Amin Al-Manmi ${ }^{3}(\mathbb{D}$, \\ Veraldo Liesenberg ${ }^{4}\left(\mathbb{D}\right.$, Syed E. Hasan ${ }^{5}$, Ahmed K. Obaid ${ }^{6,7}$ (i) and Ayad M. Fadhil Al-Quraishi ${ }^{8}$ (i) \\ 1 Iraq Geological Survey, Sulaymaniyah Office, Sulaymaniyah 334, Iraq \\ 2 Iraq Geological Survey, Al-Andalus Square, Baghdad 10068, Iraq; ahmedryaman@gmail.com \\ 3 Department of Geology, College of Science, University of Sulaimani, Sulaymaniyah 334, Iraq; \\ diary.amin@univsul.edu.iq \\ 4 Department of Forest Engineering, Santa Catarina State University (UDESC), Lages, SC 88520-000, Brazil; \\ veraldo@gmail.com \\ 5 Department of Earth \& Environmental Sciences, University of Missouri, Kansas City, MO 64110-2499, USA; \\ hasans@umkc.edu \\ 6 Department of Geology, University of Baghdad, Al-Jadiryah Street, Baghdad 10068, Iraq; \\ ahmedobaid@uobaghdad.edu.iq \\ 7 Department of Earth Sciences, University of Durham, Durham DH1 3LE, UK \\ 8 Department of Environmental Engineering, College of Engineering, Knowledge University, Erbil 44001, \\ Kurdistan Region, Iraq; ayad.alquraishi@gmail.com \\ * Correspondence: arsalan.aljaf@gmail.com
}

Received: 4 March 2020; Accepted: 13 April 2020; Published: 15 April 2020

\begin{abstract}
Iraq, a country in the Middle East, has suffered severe drought events in the past two decades due to a significant decrease in annual precipitation. Water storage by building dams can mitigate drought impacts and assure water supply. This study was designed to identify suitable sites to build new dams within the Al-Khabur River Basin (KhRB). Both the fuzzy analytic hierarchy process (AHP) and the weighted sum method (WSM) were used and compared to select suitable dam sites. A total of 14 layers were used as input dataset (i.e., lithology, tectonic zones, distance to active faults, distance to lineaments, soil type, land cover, hypsometry, slope gradient, average precipitation, stream width, Curve Number Grid, distance to major roads, distance to towns and cities, and distance to villages). Landsat-8/Operational Land Imager (OLI) and QuickBird optical images were used in the study. Three types of accuracies were tested: overall, suitable pixels by number, and suitable pixels by weight. Based on these criteria, we determined that 11 sites are suitable for locating dams for runoff harvesting. Results were compared to the location of 21 preselected dams proposed by the Ministry of Agricultural and Water Resources (MAWR). Three of these dam sites coincide with those proposed by the MAWR. The overall accuracies of the 11 dams ranged between $76.2 \%$ and $91.8 \%$. The two most suitable dam sites are located in the center of the study area, with favorable geology, adequate storage capacity, and in close proximity to the population centers. Of the two selection methods, the AHP method performed better as its overall accuracy is greater than that of the WSM. We argue that when stream discharge data are not available, use of high spatial resolution QuickBird imageries to determine stream width for discharge estimation is acceptable and can be used for preliminary dam site selection. The study offers a valuable and relatively inexpensive tool to decision-makers for eliminating sites having severe limitations (less suitable sites) and focusing on those with the least restriction (more suitable sites) for dam construction.
\end{abstract}

Keywords: dam site selection; Iraq; Khabur; AHP; WSM 


\section{Introduction}

The world's population has reached 7.6 billion [1], and more than one-third of people in the world (2.1 billion) live in drylands [2]. Iraq is an example of a semi-arid country, which experienced a significant population increase of 308\% in four decades: from 12.46 million in 1977 to 38.275 million in 2017 [1]. Water availability varies widely in Iraq: annual discharge of Iraqi rivers was between 28.16 billion $\mathrm{m}^{3}$ in a dry year (1999) and 159.89 billion $\mathrm{m}^{3}$ in a wet year (1969), with an average of 76.88 billion $\mathrm{m}^{3}$ [3]. Availability of water in the Tigris and the Euphrates rivers within Iraq has decreased due to impoundment by large dams in Turkey, Iran, and Syria, resulting in increased drought events. Twenty-one dams planned for construction as part of the Southeastern Anatolia Project (GAP) will affect water availability in the Tigris River and its tributaries. The Tigris River is estimated to lose $80 \%$ of its water from completion of GAP [4]. In addition, Iran has also started construction of several dams on the Tigris tributary, such as the Silveh Dam [5] and the Sardasht Dam [6], on the Nirawan River. These dams will become operational in the coming years, preventing a substantial quantity of the Nirawan River water from reaching Iraq. On the other hand, since 1981, only one hydraulic impoundment structure, the Mosul Dam, has been built on the Al-Khabur River within Iraq, that became fully operational on 24 July 1986. This multi-purpose dam was designed for flood control, irrigation, and electric power generation [7].

During the last four decades, geographic information systems (GIS) and remote sensing (RS) have been increasingly used for evaluation of potential sites for engineering projects [8-10]. GIS is a robust tool because of its ability to process and analyze huge volumes of data from various sources [10]. Most of these studies have used several multi-criteria decision-making (MCDM) methods to determine the most appropriate location for dam sites. The most common and widely used MCDM approaches are the fuzzy analytic hierarchy process (AHP) [11], and the weighted sum method (WSM) [12] due to their straightforward handling approach. Of these, AHP has been reported to be one of the best and most widely used approaches to handle multiple and heterogeneous factors [13], and has been successfully applied in many engineering site evaluations, including dams [14,15].

Prior to 2003, the Iraqi government had encouraged dam construction for water supply and electric power generation, and several sites were then recommended. As a result, the Ministry of Agricultural and Water Resources (MAWR) in the Kurdistan Region had preselected 21 dams for construction [16]. However, the location of these dams was based more on political consideration than technical. The Mosul Dam is a case in point, which suffers from both subsidence and siltation problems [17,18].

It is also important to note that one of the primary water management strategies to counter the impacts of flood and drought is construction of dams [14]. Besides geology, there are six key factors, which must be taken into account while evaluating dam sites: precipitation, hydrology, topography, land cover, soil types, and socioeconomics [19]. Socioeconomic aspects along with the local and regional environment-important factors in dam site selection-were not taken into account and are beyond the scope of this study. Additionally, this study excludes the northern part of the drainage basin that lies outside Iraq. These factors must be given due consideration during detailed site investigations for design and construction of the dams.

This study employed 14 predictive factors to evaluate dam sites, including suitable reservoir areas for water harvesting. The objectives of the study were two-fold: (1) to compare and evaluate the efficacy of two common MCDA methods, namely AHP and WSM, and (2) to find the most suitable sites for the construction of dams using GIS. Accordingly, we evaluated a number of potential dam sites in part of the Al-Khabur River Basin (KhRB) that lies in the Iraqi Kurdistan region (Figure 1). We used 14 thematic layers to evaluate the methods' performance. These layers include: (1) lithology, (2) tectonic zones, (3) distance to active faults, (4) distance to lineaments, (5) soil type, (6) land cover, (7) hypsometry, (8) slope gradient, (9) average precipitation, (10) stream width, (11) Curve Number (CN) Grid, (12) distance to major roads, (13) distance to towns and cities, and (14) the distance to villages. 


\section{Study Area}

The study area lies in part of the KhRB, within the Duhok governorate in the northwestern part of Iraq between latitude $36^{\circ} 55^{\prime} 33^{\prime \prime} \mathrm{N}$ and $37^{\circ} 22^{\prime} 59^{\prime \prime} \mathrm{N}$, and longitude $42^{\circ} 21^{\prime} 1^{\prime \prime} \mathrm{E}$ and $43^{\circ} 28^{\prime} 56^{\prime \prime} \mathrm{E}$ (Figure 1). The study area covers about $2599 \mathrm{~km}^{2}$ and encompasses Zakho city, Sarsing, and Batufa town, and includes over 487 villages. According to Iraqi government documents, the population of Zakho in July 2018 was 212,000 [20]. Twenty-one dams have been suggested for construction in the study area (Table A1), almost all of them can be classified (based on [21]) as large dams. These dams are estimated to store about 520 million $\mathrm{m}^{3}$ of water [16].

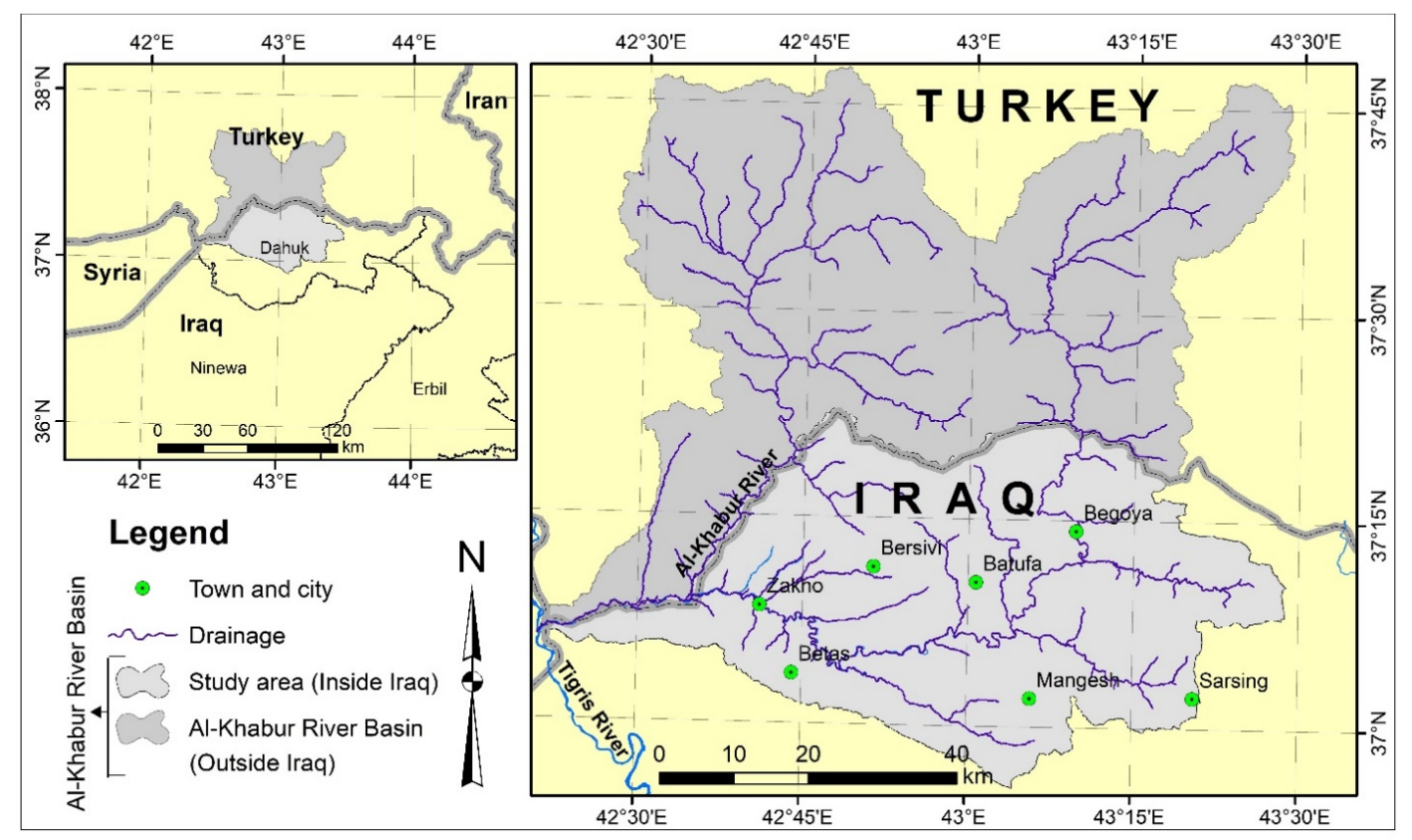

Figure 1. Location map of the Al-Khabur River Basin (KhRB).

The study area, which includes the sixth-order Al-Khabur River, carries all runoff following precipitation events in the Al-Khabur basin. The area shows significant seasonal variations in precipitation, temperature, and potential evaporation, and is characterized by wet winters and dry summers (Figure 2). The bulk of the annual precipitation $(586 \mathrm{~mm}$ ) occurs from October to May. For the 2001-2005 period, the highest average monthly precipitation, with an average value of $134.3 \mathrm{~mm}$, occurred in January. July was marked by the highest average monthly evaporation rate, with an average value of $354.7 \mathrm{~mm}$. Monthly mean temperature varied between 8.47 (January) and $33.96^{\circ} \mathrm{C}$ (July). The hottest average monthly temperature of $41.31^{\circ} \mathrm{C}$ was recorded in July, and the coldest average monthly temperature of $4.17^{\circ} \mathrm{C}$ in January. Al-Khabur River is fed by rainfall and snowmelt, resulting in peak discharge in spring and low discharges in summer and early fall. 


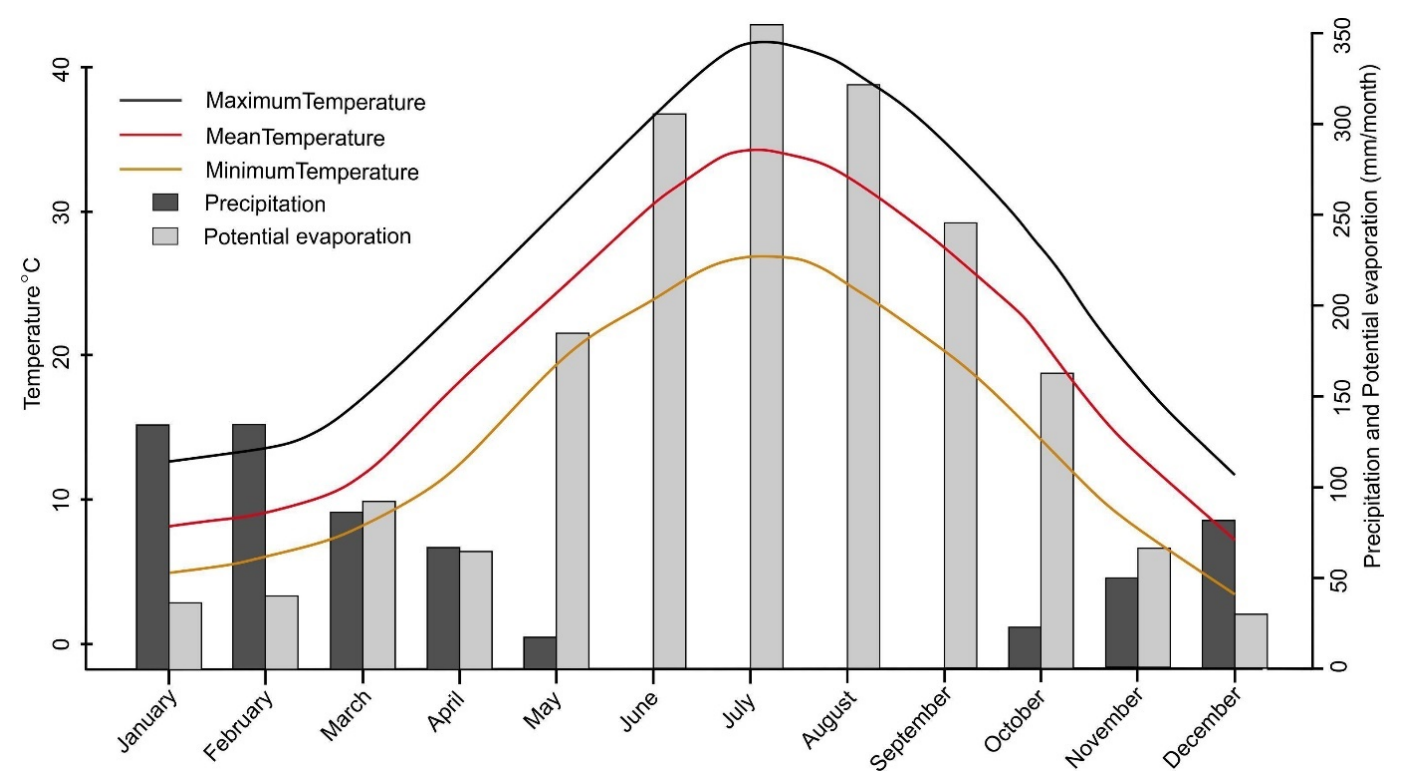

Figure 2. Monthly precipitation, potential evaporation, maximum, minimum, and mean temperature at Zakho town and surrounding areas recorded between 2001 and 2005 (Zakho meteorological station) [22].

\section{Methodology}

\subsection{Preparation of Input}

We selected and stored 14 predictive factors as thematic maps. We reviewed 10 of the high-quality papers, which were published between 2009 and 2019 (Table A2), all dealing with dam site selection [14,23-31]. More than $70 \%$ of these papers have used land cover [14,23-30], soil type $[14,23-30]$, slope gradient $[14,23,24,26,28-31]$, precipitation $[14,23,24,26,28-31]$, and $\mathrm{CN}$ grid $[23,25-28,30,31]$ as significant predictive factors for dam site selection. Fifty percent of the papers used different factors to calculate stream order [23-25,30], and between $40 \%$ and $20 \%$ of the papers used elevation $[25,27,30,31]$, lithology [14,29,31], tectonic zone [14,29,31], distance to active fault $[14,29,31]$, distance to lineaments $[23,30,31]$, distance to villages [14,29,30], distance to towns and cities [14,29], discharge $[14,31]$, and distance to roads $[14,30]$ as predictive factors. However, less than $10 \%$ of these papers used distance to deposits of geologic materials (borrow areas) [14], total dissolved solids (TDS) [31], evaporation [29], and volume of depressions factors [25]. We selected 14 of these key factors for this study, while the other four factors (i.e., distance to borrow areas, total dissolved solids (TDS), evaporation, and volume of depressions) were excluded, as they are not commonly used. At the same time, two factors, distance to roads, and stream width, although not commonly used, were evaluated experimentally. In other words, we eliminated factors that decrease the accuracy of dam site selection, and retained those that increase the accuracy of dam site selection. We used $>3$ order streams for their high storage capacity.

The pixel sizes of the thematic maps were resampled to obtain the exact spatial resolution as the pixel size of the digital elevation model (DEM) from the Shuttle Radar Topography Mission (SRTM) (i.e., $30 \mathrm{~m}$ spatial resolution). The predictive input factors are either continuous or discrete. Factors such as elevation, distance to road, and slope gradient, are continuous, while soil, land cover, and lithology are discrete (Table 1). We used spatial analyst tools of ArcGIS to convert the continuous to discrete factors. To do that, we classified each continuous input factor into five major classes, which are: most suitable, suitable, moderately suitable, less suitable, and not suitable. The weight of the five main classes are 1,3,5,7, and 9, where the not suitable is 1 and the most suitable is 9 . We used the natural breaks method because it allows to reduce the variance within classes and maximizes the variance between classes [32]. The number and boundary of classes can significantly influence the 
results of the statistical methods [33]. The classes in the discrete input factors were assigned to have the same five classes (i.e., most suitable, suitable, moderately suitable, less suitable, and not suitable).

Table 1. Factors' relations towards the suitable dam site evaluation.

\begin{tabular}{|c|c|c|c|c|c|}
\hline No. & Factor & $\begin{array}{l}\text { Relationship } \\
\text { Type }\end{array}$ & Type of Data & $\begin{array}{l}\text { Relation } \\
\text { Intensity }\end{array}$ & Data Source \\
\hline 1 & Lithology & No relation & Discrete & Very strong & $\begin{array}{l}\text { Iraq Geological } \\
\text { Survey }\end{array}$ \\
\hline 2 & Tectonic zones & No relation & Discrete & Very weak & $\begin{array}{l}\text { Iraq Geological } \\
\text { Survey }\end{array}$ \\
\hline 3 & $\begin{array}{l}\text { Distance to active fault } \\
(\mathrm{m})\end{array}$ & Inverse & Continuous & Weak & $\begin{array}{l}\text { Iraq Geological } \\
\text { Survey }\end{array}$ \\
\hline 4 & $\begin{array}{l}\text { Distance to the } \\
\text { lineaments }\end{array}$ & Inverse & Continuous & Weak & USGS/Landsat-8 \\
\hline 5 & Soil & No relation & Discrete & Moderate & FAO/HWSD \\
\hline 6 & Land cover & No relation & Discrete & Weak & USGS/Landsat-8 \\
\hline 7 & Elevation & No relation & Continuous & Moderate & USGS/SRTM \\
\hline 8 & Slope gradient $\left(^{\circ}\right)$ & Inverse & Continuous & Strong & DEM \\
\hline 9 & Precipitation & Direct & Continuous & Moderate & NASA/TRMM \\
\hline 10 & Stream width & Direct & Continuous & Strong & QuickBird \\
\hline 11 & CN grid & Direct & Continuous & Moderate & DEM \\
\hline 12 & Distance to road & Inverse & Continuous & Very weak & HIC \\
\hline 13 & $\begin{array}{c}\text { Distance to towns and } \\
\text { cities }(\mathrm{m})\end{array}$ & Inverse & Continuous & Very weak & HIC \\
\hline 14 & Distance to villages (m) & Inverse & Continuous & Very weak & HIC \\
\hline
\end{tabular}

USGS-United States Geological Survey; FAO-Food and Agriculture Organization of the United Nations: HWSD-Harmonized World Soil Database; NASA-National Aeronautics and Space Administration; TRMM-Tropical Rainfall Measuring Mission; and HIC-Humanitarian Information Centre for Iraq.

\subsection{Suitable Dam Site Selection Model}

Although several MCDM methods are available, there is no specific method that could be considered most suitable for all types of decision-making situations [34-36]. A big criticism of MCDM is the fact that different approaches can yield different results if applied to the same problem [37]. The determination of a suitable MCDM method is thus not an easy task and the focus should be on careful selection of the method [34]. The literature presents several practical applications of comparative analyses of different MCDM methods [11,12,38-46]. In this study, we used WSM and AHP to determine suitable locations for dams.

\subsubsection{Weighted Sum Method (WSM)}

WSM does not take into account the significant deficiencies that can occur as input factors [47], given that all factors have equal weight. In the first step, we classified each factor into five classes. These were 1, 3, 5, 7, and 9 for the not suitable, less suitable, moderately suitable, suitable, and most suitable for dam site selection, respectively. The weight of these five classes was determined according to the suitability of each class to locate the dam, as shown in Table A3 (column "Rank") and Table 1 (column "Relation intensity"). We relied mainly on previous literature, such as References [9,14,30], and our own expert opinion to compute the weights for the factors. The next step is summation of all factors following Equation (1), suggested by Fishburn [12].

$$
W S M=\sum_{i=1}^{n} w_{j} a_{i j}
$$

where $n$ is the number of factors, $a_{i j}$ is the actual value of the $i$ of the $j$ criterion, and $w_{j}$ is the weight of the $j$ criterion. 


\subsubsection{Analytic Hierarchy Process (AHP)}

In 1990, Saaty proposed the AHP method, an easy-to-use method that calculates the index weight by comparing the predictive factors with each other [48]. It is one of the most commonly used methods for dam site selection. The GIS environment was used to determine suitable sites for dam, and ratings of each predictive factor are provided on a five-point continuous scale. The weight of each predictive factor was estimated depending on the relation intensity of the factors that influence dam site selection (Table 1). These weights have been computed depending mainly on the previous literature, such as References $[9,14,30]$, and our own expert opinion. The map of suitable sites for dams is computed by the raster overlay algorithm, using Equation (2) [49]:

$$
A H P=\sum_{i=1}^{n} x_{i} w_{i}
$$

where $x_{i}$ is the value of predictive factor $i$ (where $i=$ (predictive factors listed in Table 1)), $w_{i}$ is the weight for predictive factor $i$, and $n$ is the number of predictive factors. We correlated all predictive factors used by normalizing their scales and units, using the following equation (Equation (3)):

$$
Z_{i}=\frac{X_{i}-X_{\min }}{X_{\max }-X_{\min }}
$$

where $Z_{i}$ is the normalized value of pixel, $X_{i}$ is the value of pixel, $X_{\text {min }}$ is the minimum value of pixel, and $X_{\text {max }}$ is the maximum value of pixel.

As the dam sites are located within the river courses, we made sets of buffer zones (250,500, and $1000 \mathrm{~m}$ ) around the drainage networks. The two maps (i.e., WSM and AHP) were intersected with these three buffer zones. The pixels within these three zones that received average value $\geq$ moderately suitable, were selected for dam site location.

\subsubsection{Accuracy Assessment and Dam Site Selection}

We followed Noori [14] by modifying the segmentation accuracy assessment [50] to evaluate the results of AHP and WSM methods. The method used the identified number of segments to calculate the summation of distances from suitable pixels to the reference point. Initially, the 21 large dams (Table A1) proposed by MAWR were used as reference points [16]. Thereafter, the resulting maps of WSM and AHP methods were categorized into five classes: most suitable, suitable, moderately suitable, less suitable, and not suitable for location of dams. We created sets of buffer zones $(250,500$, and $1000 \mathrm{~m}$ ) around the reference points. The total pixels' number, the suitable pixels' numbers, and the distance between the reference and the pixels within the buffer, were calculated. Finally, overall accuracy (OA) of the suitable pixels was calculated using Equations (4), (5), and (6):

$$
\begin{gathered}
A_{s}=\frac{N_{s}}{\sum N} \\
A_{w}=\frac{\sum W}{\sum N} \\
O_{A}=\frac{A_{s}+A_{w}}{2}
\end{gathered}
$$

where $A_{s}$ is the accuracy of the suitable pixels by number, $N_{s}$ is the number of suitable pixels, $\sum N$ is the total pixels, $A_{w}$ is the accuracy of the suitable pixel by weight, $\sum W$ is the summation of weights of the total pixels, and $O_{A}$ is the overall accuracy.

In order to refine our approach, we also applied the threshold operation. The selection of the threshold values for the suitable method was determined experimentally. The final thresholded raster of 
the suitable method was then used to locate the areas representing potential dam sites. These locations have been determined using shapefile of point feature type.

\section{Predictive factors}

\subsection{Geological Factors}

Structural, tectonic, and lithological variabilities affect the strength and stability of geologic materials [33,51]. Accordingly, we used four geological factors as input parameters: (1) lithology, (2) tectonic zones, (3) distance to active fault, and (4) distance to lineaments.

Two geological maps from published reports of Sissakian [52] and Al-Mousawi [53], at a scale of 1:250,000, were used in this study. These maps were scanned at 300 dots per inch (dpi) and georeferenced to the Universal Transverse Mercator (UTM) coordinate system (zone 38 north). The lithological units, tectonic units, and faults were digitized in a GIS database. The lithology and tectonic zones shapefiles were converted to raster format using a spatial resolution of $30 \mathrm{~m}$.

Lithology of the study area includes 24 rock units (Figure 3). This raster layer was used as the lithological factor. The Ordovician period includes one unit (i.e., Khabour Formation) consisting of sandstone and shale rocks. Rock units of the Carboniferous-Jurassic periods consist of limestone, shale, marl, and siltstone. Rocks of the Cretaceous period comprise limestone, marl, dolostone, and sandstone. The Tertiary period units consist of clastic rocks such as sandstone, conglomerate, siltstone, claystone, and marl. Quaternary sediments (Table 2) include residual soil, slope debris, and flood plain deposits $[52,54]$.

According to Foad [53], the study area is located within the Unstable Shelf, which is a part of the Zagros Fold-and-Thrust Belt. This belt is approximately $2000 \mathrm{~km}$ long, extending from southeast Turkey through Iraq to southern Iran [55-60]. The unstable shelf includes the Imbricated Zone (IZ) and the High Folded Zone (HFZ). The IZ and HFZ cover $24 \%$ and $76 \%$ of the study area, respectively. The IZ lies to the north of the study area, and the HFZ is located to the south (Figure 3).

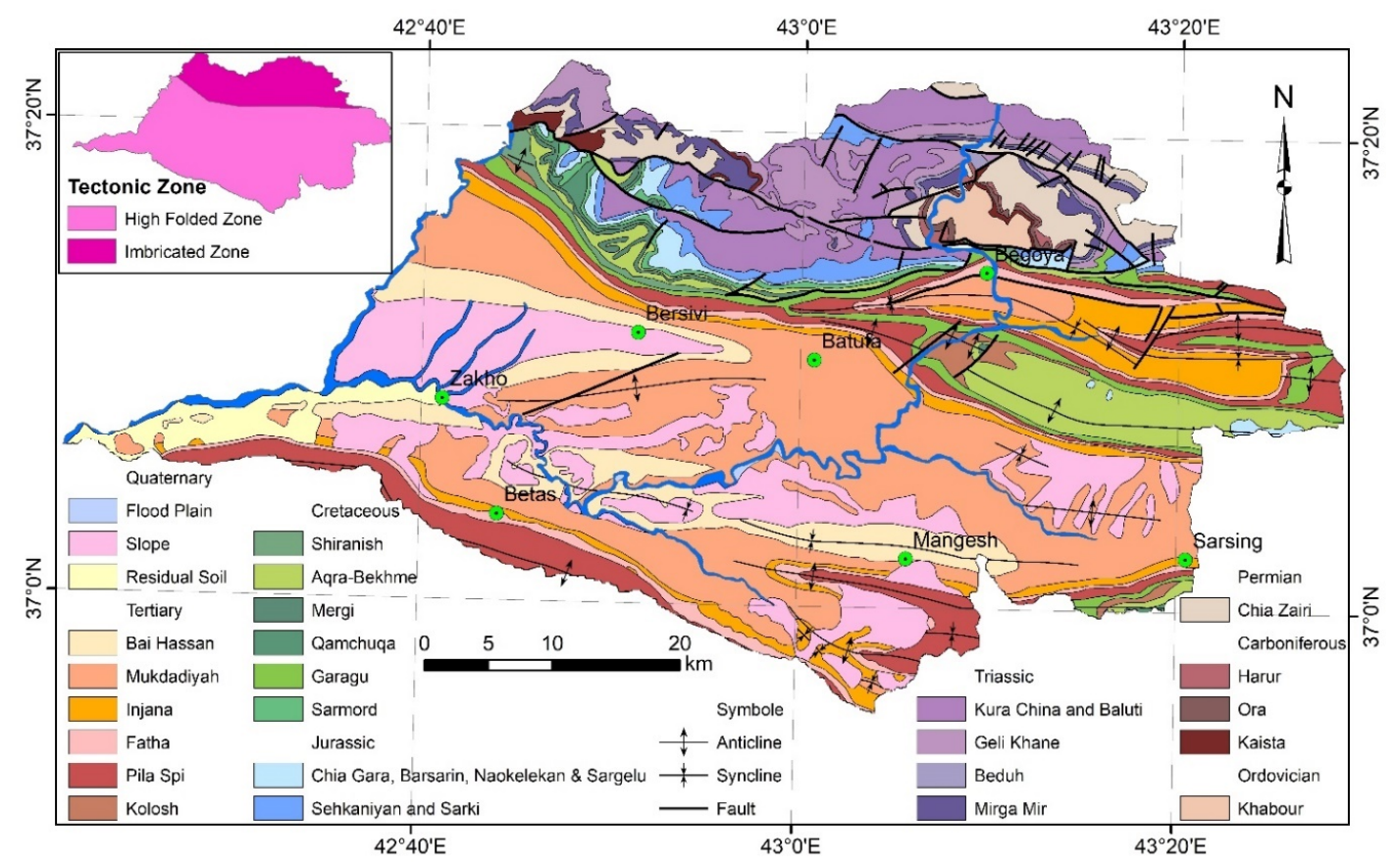

Figure 3. Geological [52,53] and tectonic map [53] of the study area. 
Table 2. Brief descriptions of geological formations and lithological units in the study area.

\begin{tabular}{|c|c|c|c|c|}
\hline No. & Lithological Unit & Epoch & Suitability & Description \\
\hline 1 & Flood Plain & Holocene & Not suitable & Silt, clay, and sand \\
\hline 2 & Slope & Pleistocene-Holocene & Not suitable & $\begin{array}{l}\text { Rock fragments cemented by } \\
\text { calcareous materials }\end{array}$ \\
\hline 3 & Residual Soil & Holocene & Not suitable & $\begin{array}{l}\text { Clayey, with limestone rock } \\
\text { fragments }\end{array}$ \\
\hline 4 & Bai Hassan & Pliocene & Less suitable & $\begin{array}{l}\text { Conglomerate, claystone, } \\
\text { sandstone, and siltstone }\end{array}$ \\
\hline 5 & Mukdadiyah & $\begin{array}{l}\text { Late Miocene-Early } \\
\text { Pliocene }\end{array}$ & Not suitable & $\begin{array}{c}\text { Pebbly sandstone, siltstone, and } \\
\text { claystone }\end{array}$ \\
\hline 6 & Injana & Late Miocene & $\begin{array}{l}\text { Moderately } \\
\text { suitable }\end{array}$ & $\begin{array}{c}\text { Sandstone, siltstone, and } \\
\text { claystone }\end{array}$ \\
\hline 7 & Fatha & Middle Miocene & Not suitable & $\begin{array}{l}\text { Claystone, marl, limestone, } \\
\text { gypsum, and siltstone }\end{array}$ \\
\hline 8 & Pilaspi & Middle-Late Eocene & Suitable & Bedded dolostone, and limestone \\
\hline 9 & Kolosh & Early Paleocene & Not suitable & Black clastics \\
\hline 10 & Shiranish & Late Cretaceous & Less suitable & $\begin{array}{l}\text { Marl, marly limestone, and } \\
\text { limestone }\end{array}$ \\
\hline 11 & Aqra-Bekhme & Late Cretaceous & Most suitable & Limestone \\
\hline 12 & Mergi & Late Cretaceous & $\begin{array}{l}\text { Moderately } \\
\text { suitable }\end{array}$ & Limestone and marl \\
\hline 13 & Qamchuqa & Early Cretaceous & Suitable & $\begin{array}{l}\text { Massive and bedded dolostone } \\
\text { and limestone }\end{array}$ \\
\hline 14 & Garagu & Late Cretaceous & Suitable & Marl, sandstone, and limestone \\
\hline 15 & Sarmord & Early Cretaceous & Suitable & Limestone and marl \\
\hline 16 & $\begin{array}{c}\text { Chia, Gara, Barsarin, } \\
\text { Naokelekan and } \\
\text { Sargelu }\end{array}$ & Late Jurassic & Less suitable & $\begin{array}{c}\text { Limestone, sandstone, marl, and } \\
\text { shale }\end{array}$ \\
\hline 17 & Sehkaniyan and Sarki & Early Jurassic & $\begin{array}{l}\text { Moderately } \\
\text { suitable }\end{array}$ & Limestone and shale \\
\hline 18 & Kura China and Baluti & Late Triassic & Suitable & Limestone and shale \\
\hline 19 & Geli Khane & Middle Triassic & Suitable & $\begin{array}{l}\text { Limestone, shale, marl, and } \\
\text { siltstone }\end{array}$ \\
\hline 20 & Beduh & Early Triassic & Not suitable & Limestone, shale, and marl \\
\hline 21 & Mirga Mir & Early Triassic & Less suitable & Limestone and shale \\
\hline 22 & Chia Zairi & Late-Early Permian & Not suitable & Limestone and shale \\
\hline 23 & Harur & Early Carboniferous & Less suitable & Limestone and shale \\
\hline 24 & Ora & Early Carboniferous & Not suitable & Limestone, shale, and marl \\
\hline 25 & Kaista & Late Devonian & Less suitable & Siltstone, limestone, and shale \\
\hline 26 & Khabour & $\begin{array}{l}\text { Late- Early } \\
\text { Ordovician }\end{array}$ & Not suitable & Sandstone and shale \\
\hline
\end{tabular}

Distance to lineaments and active faults have been used as predictive factors because they represent potential weakness zones. Since highly faulted areas are not suitable for dam construction [61], dam sites should be located at least $100 \mathrm{~m}$ away from lineaments and active faults [14]. Based on these requirements, we implemented all parameters shown in Table 3 [62]. The result was exported as a shapefile and modified within the ArcGIS [63] environment.

We obtained information on active faults by digitizing the two series of geological maps mentioned above $[52,54]$. The study area includes 53 fault segments, four of which are normal faults, and 11 are thrust faults, while the rest are unclassified (Figure 3). The total length of the faults is $\sim 297.1 \mathrm{~km}$. Interestingly, 10 of them are $>2 \mathrm{~km}$ in length. The main direction of the thrust faults is NW-SE, while the main directions of the rest of the faults are NE-SW (Figure 3). Distance to the faults ranges between 0 and $34.02 \mathrm{~km}$ (Figure 4A). The faults shapefile was used to prepare the raster of faults factor. The Euclidean distance to the closest faults was calculated for each cell.

According to Javhar et al. [62], the best band for lineaments extraction from Landsat-8/Operational Land Imager (OLI) is the spectral band 5 (near infrared: $0.85-0.88 \mu \mathrm{m}$ ). Therefore, we used this spectral band acquired on 24 September 2018 [64] to extract the lineaments. The scene was cropped to cover the study area. The lineaments were mapped using lineament extraction tool available in the PCI Geomatica software [65]. 
Table 3. Threshold parameters and values of lineament extraction [62].

\begin{tabular}{cc}
\hline Parameters & Value \\
\hline RADI (in pixels) & 8 \\
GTHR (in range, 0-255) & 60 \\
LTHR (in pixels) & 20 \\
FTHR (in pixels) & 3 \\
ATHR (in degrees) & 15 \\
DTHR (in pixels) & 20 \\
\hline
\end{tabular}

RADI-radius of filter in pixels; GTHR-threshold for edge gradien; LTHR-threshold for curve length; FTHR-threshold for fitting line error; ATHR-threshold for angular difference; and DTHR-threshold for linking distance.

The lineaments shapefile was used to prepare the raster of lineament factors. The Euclidean distance to the closest lineament was calculated for each cell (Figure 4A). The study area includes 2045 lineaments, most of them trending in NE-SW and NW-SE direction. The total length of faults is $\sim 2114.9 \mathrm{~km}$. More than $63.2 \%$ of the lineaments are $<1 \mathrm{~km}$ in length. The distance of pixels to the lineaments ranges between 0 and $3.394 \mathrm{~km}$ (Figure 4B).
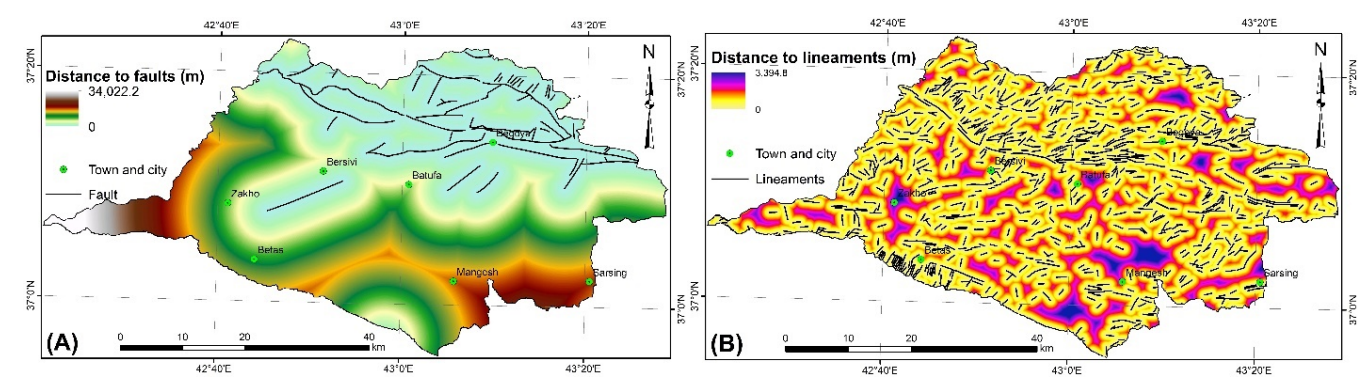

Figure 4. Maps of (A) distance to faults, (B) distance to lineaments.

\subsection{Environmental Factors}

Soil types were obtained from Harmonized World Soil Database (HWSD) [66]. This database consists of a $1 \mathrm{~km}$ (or 30 arc-second) raster image. Clay soils were considered more suitable because of their low permeability and greater water-holding capacity [67-69]. Four groups of soil are exposed in the study area (black dots; Figure 5), which are classified as leptosols, luvisols, vertisols, and calcisols (Figures 5 and 6A; Table 4). Leptosols soil group includes three sub groups (A, B, and C in Table 4). Figure 5 shows the texture of the soil types in the study area. The most suitable soil type for dam location is vertisols, composed of $43 \%$ clay.

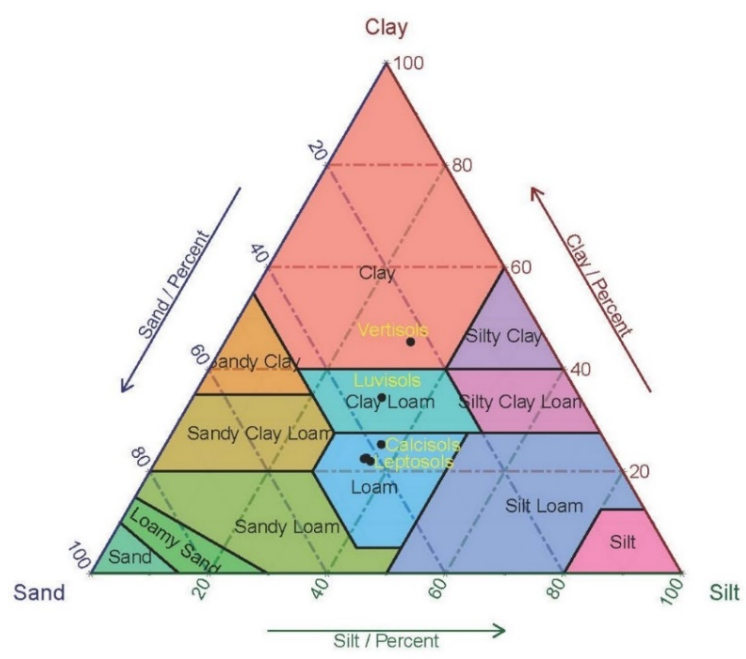

Figure 5. Soil textural classification [70]. Small dots indicate the percentage of silt, clay, and sand. 
Table 4. Soil group types in the study area.

\begin{tabular}{|c|c|c|}
\hline Soil Group & Soil Type & Suitability \\
\hline Leptosols A & \multirow{3}{*}{$\begin{array}{c}\text { Lithosols and Eutric Cambisols } \\
\text { Lithosols, Rendzinas, and Calcic Xerosols } \\
\text { Lithosols, Calcaric Regoso, and Calcic } \\
\text { Xerosols }\end{array}$} & Not suitable \\
\hline Leptosols B & & Not suitable \\
\hline Leptosols C & & Not suitable \\
\hline Luvisols & \multirow{3}{*}{$\begin{array}{c}\text { Chromic Luvisols, Calcic Cambisols, } \\
\text { Lithosols, and Calcaric Regoso } \\
\text { Chromic Vertisols, and Calcic Xerosols } \\
\text { Calcic Xerosols, Rendzinas, and Chromic } \\
\text { Vertisols }\end{array}$} & Moderately suitable \\
\hline Vertisols & & Most suitable \\
\hline Calcisols & & Less suitable \\
\hline
\end{tabular}

We performed a supervised classification using the Support Vector Machine (SVM) algorithm proposed by Vapnik [71] to discriminate the seven major land cover classes. The selected land cover classes are orchard or tree farm class, mountain brush mixture of oak brush class, cultivated land or bare land class, water body class, road class, built-up land class, and bare land class (Figure 6B). SVM is a supervised nonparametric method developed from statistical machine learning. It is used to solve complicated class distributions in multi and hyperspectral data [72]. Input data layers contain the seven multispectral reflectance bands of Landsat-8/OLI acquired on 24 September 2018, with a spatial resolution of $30 \mathrm{~m}$. A radial basis function was selected as kernel type, and the penalty parameter was 100. The gamma in kernel function was the inverse of the band numbers used in the data input $[72,73]$. Such procedures are in agreement with previous research conducted by Othman and Gloaguen [74] and Yang [73]. In addition to fieldwork, we used the QuickBird images to select both training and validating datasets for the seven major land cover classes. A total of 615 pixels was selected randomly for training. Another dataset consisting of 310 pixels was used for validation to calculate the OA and Kappa coefficient (K). The classification accuracy was estimated by defining the OA [75] and the K [76], which is a measure of agreement between the classified map and the true reference data. The realized $\mathrm{OA}$ and $\mathrm{K}$ are $93.08 \%$ and 0.8850 , respectively.

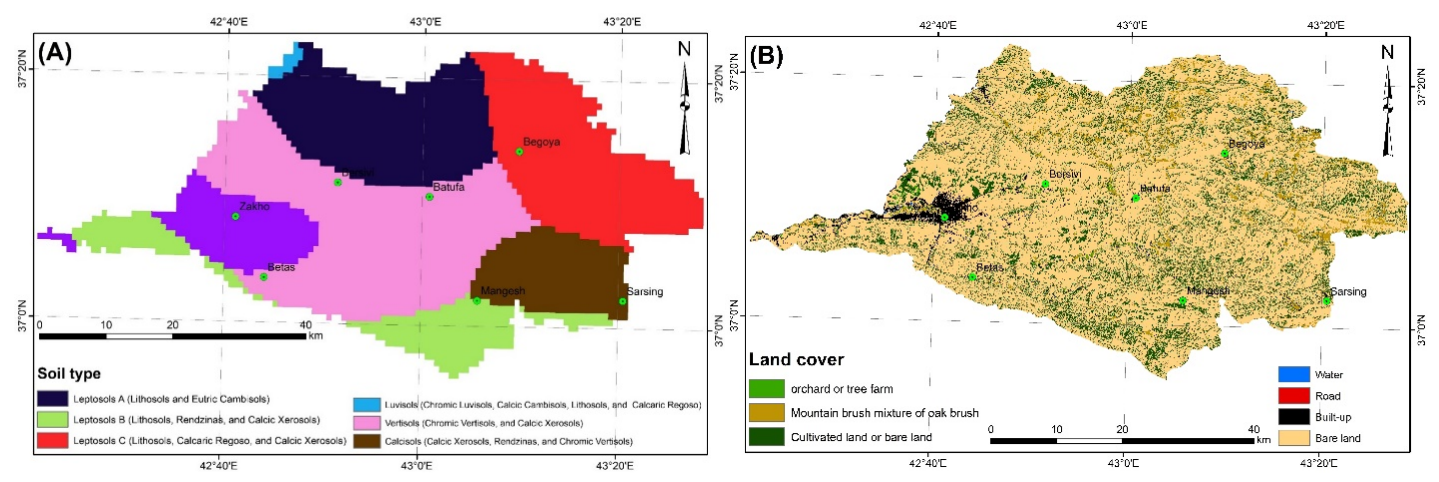

Figure 6. Maps are showing: (A) soil types [66], and (B) land cover (LC) units.

\subsection{Topographical Factors}

We used two topographic attributes, elevation and slope gradient. Using the DEM/SRTM, we classified moderate elevation lands as most suitable, and the low and high elevation lands less suitable for locating dam sites [14] because low lands are prone to flooding [77,78]. We mosaiced four scenes of SRTM, with a spatial resolution of 1 arc-second. The data was reprojected to UTM $\mathrm{Z} 38 \mathrm{~N}$, resulting in a spatial resolution of $30 \mathrm{~m}$. We resampled the DEM using the neighbor resampling method. The range of elevation in the study area was between 335 and $2418 \mathrm{~m}$ above sea level (a.s.l.; Figure 7A). The mean elevation was $988 \mathrm{~m}$ a.s.l. 


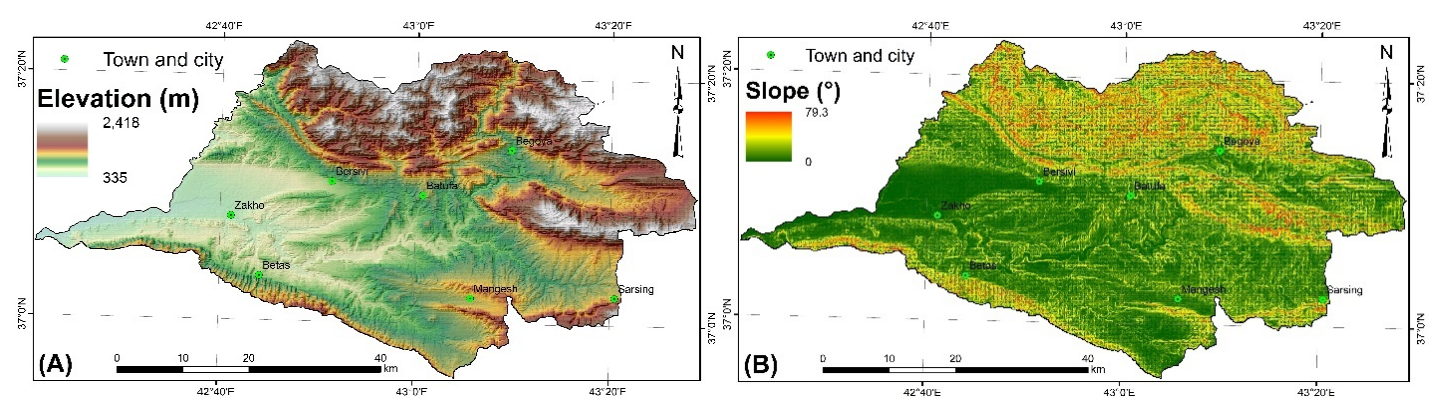

Figure 7. Maps of: (A) elevation, and (B) slope gradient of the study area.

In addition, DEM was also used to extract slope attribute. The steepness of slopes is a major factor in dam site selection. Lands with gentle slopes are more suitable for dam sites location, and vice versa [79]. Hamzeh [80] stated that areas with slope $>15^{\circ}$ are unsuitable for dam sites [19]. Slope gradient in the study area ranged between flat and $79.3^{\circ}$ (Figure 7B), with an average slope gradient of $13.8^{\circ}$. We determined slope pixels between $0^{\circ}$ and $2^{\circ}$ to be most suitable and slope pixels $>30^{\circ}$ to be not suitable for dam site location.

\subsection{Hydrological Factors}

We also used the TRMM data to determine precipitation in the study area. The TRMM [81] was a joint space mission between NASA and the Japan Aerospace Exploration Agency (JAXA). It was designed to measure the rainfall of tropical and subtropical regions of the world. The type of data used is TRMM (3B43-V7), which combines monthly precipitation with a spatial resolution of $0.25^{\circ} \times 0.25^{\circ}$ [82]. We calculated the average of annual precipitation using the monthly TRMM (3B43-V7) data acquired from September 2002-August 2017. Thirty pixels were selected to cover the study area and the surrounding regions to create distribution of the precipitation factor. To obtain a continuous coverage, we converted these pixels to points, then, we interpolated point-wise precipitation data using an inverse distance weighting (IDW) method.

Approximately $50 \%$ of the runoff in the entire KhRB enters the streams inside the Iraqi portion of the basin [83]. Therefore, besides precipitation, river discharge is a significant factor that controls the amount of water stored in the dam reservoir. Lack of hydrological information is made worse in the Al-Khabur mountainous region due to either a total lack of river gauges or poor quality of the limited in-situ monitoring data. Therefore, we measured stream width of the stream networks as an alternative to in-situ river discharge data.

Suitability of TRMM data in the study area was evaluated by making a comparison with the observed precipitation dataset of the Zakho meteorological station. The data from 62 recorded precipitation measurements, covering the period from September 2002 to December 2007, were used. We found that there is a strong linear relationship between the monthly TRMM dataset and the observed precipitation, where the coefficient of determination $\left(R^{2}\right)$ is 0.853 and the $p$-value is $<0.05$ (Figure 8A). The slope and intercept were 0.9124 and 9.5485, respectively. The TRMM 3B43-V7 is a valuable tool for mapping water resources that shows good agreement with the ground stations' data [84]. Precipitation varies from $562.85 \mathrm{~mm} \cdot \mathrm{yr}^{-1}$ in the southern part of the study area to $785 \mathrm{~mm} \cdot \mathrm{yr}^{-1}$ in the north (Figure 8B). 

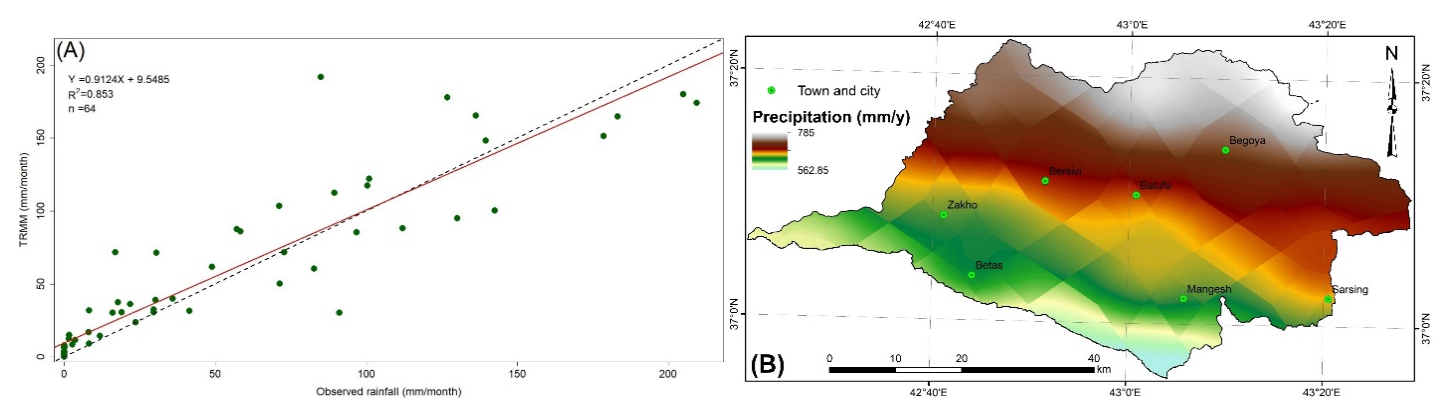

Figure 8. (A) Comparison of observed rainfall from Duhok metrological station and the Tropical Rainfall Measuring Mission (TRMM) data for the pixel located at the same site for the period September 2002 to March 2010, and (B) precipitation distribution in the study area.

Drainage network was extracted using tectonics from digital elevation models (TecDEM) 2.2, a MATLAB-based software, which permits the extraction of geomorphologic indices from DEM [85-87]. Ramakrishnan [23], Grum [24], Tiwari [25], and Singhai [30] used stream order to estimate the storage capacity of the sub-basins (Table A2). We selected streams belonging to order 3 or higher for locating dam sites. The long streams were split into multi segments to be less than $10 \mathrm{~km}$. The width of each stream was measured using 23 cloud-free QuickBird scenes, acquired between 24 and 28 July 2005. We used these older scenes because no recent QuickBird data was available. We considered areas that have no streams or those where streams width is $<60 \mathrm{~cm}$ (the spatial resolution of QuickBird imagery)to be unacceptable for dam construction (Figure 9A). Three buffer maps (250, 500, and $1000 \mathrm{~m}$ ) were created for locating dam sites in the study area.

DEM was used to calculate the $\mathrm{CN}$ grid. $\mathrm{CN}$ is an empirical parameter commonly used in hydrology for predicting direct runoff or infiltration from rainfall excess [88-91]. It is a dimensionless parameter and ranges from 0 to 100 .

We estimated the $\mathrm{CN}$ per pixel by matching the rainfall, soil group, and land cover maps (Equations (7) and (8); [30]. The Geospatial Hydrologic Modeling Extension, HEC-GeoHMS tool, has been used [92].

$$
\begin{gathered}
Q=\frac{\left(P-I_{a}\right)^{2}}{P-I_{a}+S} \\
S=\left(\frac{25,400}{C N}\right)-254
\end{gathered}
$$

where $Q$ is runoff (mm), $P$ is rainfall ( $\mathrm{mm}), I_{a}$ is the initial abstraction, or the amount of water before runoff, which has generally been assumed that $I_{a}=0.2 \mathrm{~S}$, and $\mathrm{S}$ is the potential maximum soil moisture retention after runoff begins. The $S$ is calculated using Equation (2) and denoted as per the CN $[93,94]$.

The $\mathrm{CN}$ value of $100(\mathrm{~S}=0)$ represents low runoff potential that suggests an impermeable catchment having the maximum runoff-generation capability. A CN value of 0 represents increasing runoff potential of $S$ (i.e., $S=\infty$ ), which suggests an infinitely abstracting catchment having zero runoff-generation capability [19]. As shown in Figure 9B, the CN at the KhRB ranges from 30 to 100. The central area of KhRB represents higher runoff potential, with lower runoff potential in the northern and southern parts of KhRB. 

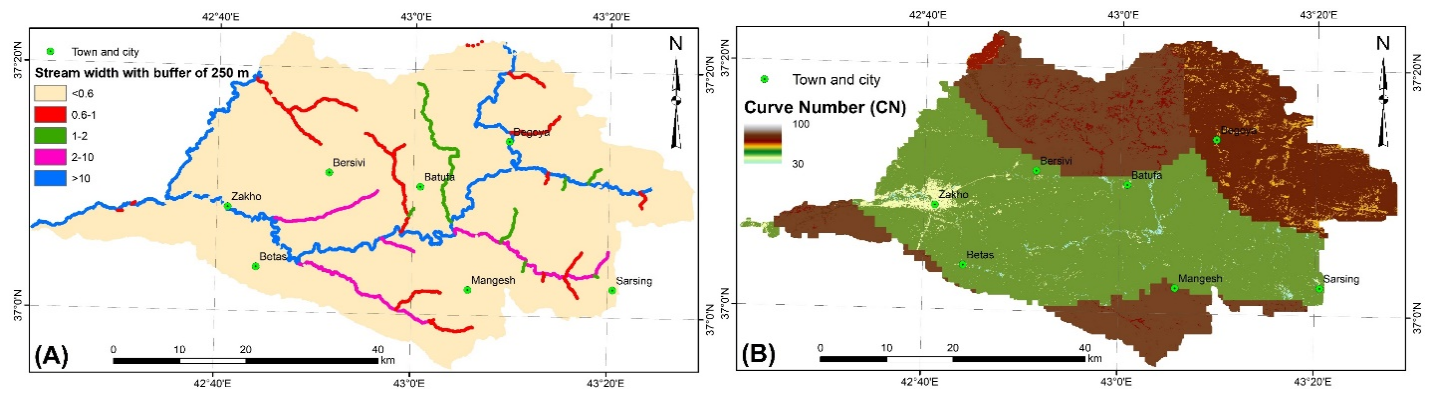

Figure 9. Maps of (A) stream width map, and (B) Curve Number $(\mathrm{CN})$ of the study area.

\subsection{Socioeconomics Factors}

We used three socioeconomics factors: (1) distance to roads (m), (2) distance to towns and cities (m), and (3) distance to villages (m). The informatic layers of roads, villages, towns, and cities were obtained from United Nations Office for the coordination of Humanitarian Affairs-Iraq (UNOCHA-IRAQ) [95]. Although the distance to roads has a low impact on dam site suitability, existence of roads and settlements near proposed dam sites contribute to reducing transportation cost [14]. Buffers surrounding the villages, towns, cities, and roads were used to calculate the distance to villages, towns, cities, and roads (Figures 10 and 11). The farthest distances between each pixel in the study area and the roads, towns, and villages are about $11.5,19.3$, and $5.4 \mathrm{~km}$, respectively.
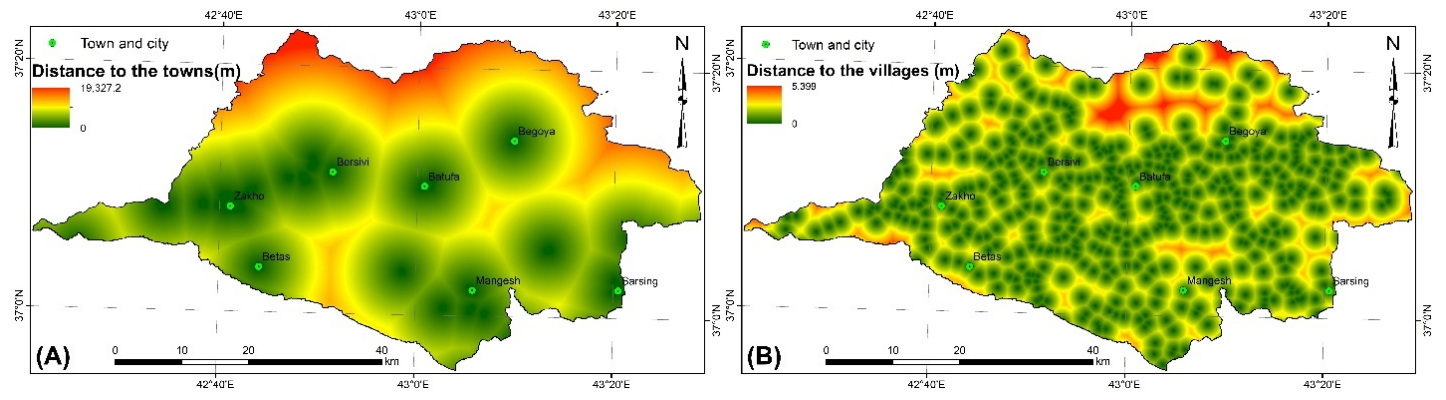

Figure 10. Maps of the factors: (A) distance to towns and cities, and (B) distance to villages.

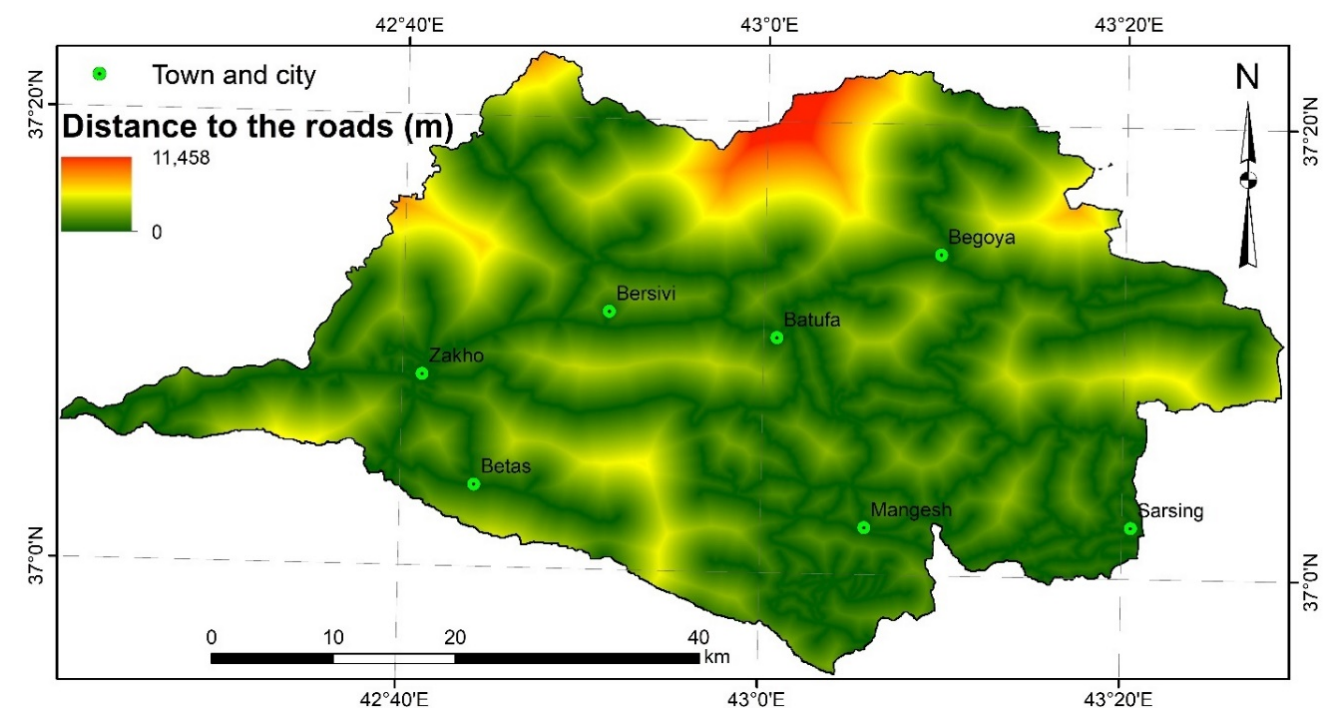

Figure 11. Map of distance to road. 


\section{Results}

We tested 14 different combinations of predictive factors in order to select the best individual combination for the WSM and AHP models. The relationships between dam sites and dam sites' predictive factors using WSM and AHP models are shown in Table A3.

Each factor has a specific predictive weight that varies between WSM and AHP. The predictive weight in the two models represents the normalized WSM and AHP ranks, respectively. The ranges of the predictive factor weights can be calculated by applying the prediction model Equations (3) and (4).

\subsection{Identification of Suitable Sites for Dams by the WSM and AHP Models}

Dam site selection maps have been prepared using two different models (Figure 12). The predictive factors were evaluated qualitatively by adding and removing the predictive factors (experimental method) to select the significant factors and to enhance the prediction accuracy of the dam site selection maps. In other words, we removed the factors that decrease the accuracy of dam site selection and retained those that increase the accuracy of dam site selection.

Qualitative evaluation shows that, for the AHP method, the most significant subfactors are: Aqra-Bekhme lithology, soil type of Chromic Vertisols, and Calcic Xerosols, land cover, type of water, distance to faults $>1000 \mathrm{~m}$, distance to faults $>3000 \mathrm{~m}$, areas having elevation between 700 and $800 \mathrm{~m}$ a.s.l., flat areas, rivers that have width $>10 \mathrm{~m}$, areas that have $\mathrm{CN}>87$, distance to roads $<1000 \mathrm{~m}$, distance to cities and towns $>2500 \mathrm{~m}$, and distance to villages $>1000 \mathrm{~m}$ (Table A3).

Statistical models based on the AHP and the WSM method revealed the most suitable areas for dam site location. Suitability of dam sites using the WSM and AHP models are shown in Figure 12. These maps display the suitable and the most suitable areas in magenta and blue color respectively, and are located mainly in the center of the study area. The range of the data distribution of the 1000 $\mathrm{m}$ buffer for the WSM and AHP is between 0 and 1. The mean of the AHP suitability map is greater than the mean of the WSM suitability map, and the standard deviation of the AHP model is less than the standard deviation of the WSM model in all selected buffer zones (1000, 500, and 250). The mean of the WSM and AHP data are 0.47 and 0.56 respectively, while the standard deviation is 0.2 and 0.14 , respectively. The most suitable area of the WSM and the AHP models are 4,918,500 $\mathrm{m}^{2}$ and $10,188,900 \mathrm{~m}^{2}$, respectively. The difference between the AHP and WSM map shows that the suitability value is higher in almost all pixels that are present in the AHP model, with only a few pixels showing the opposite (Figure 13).

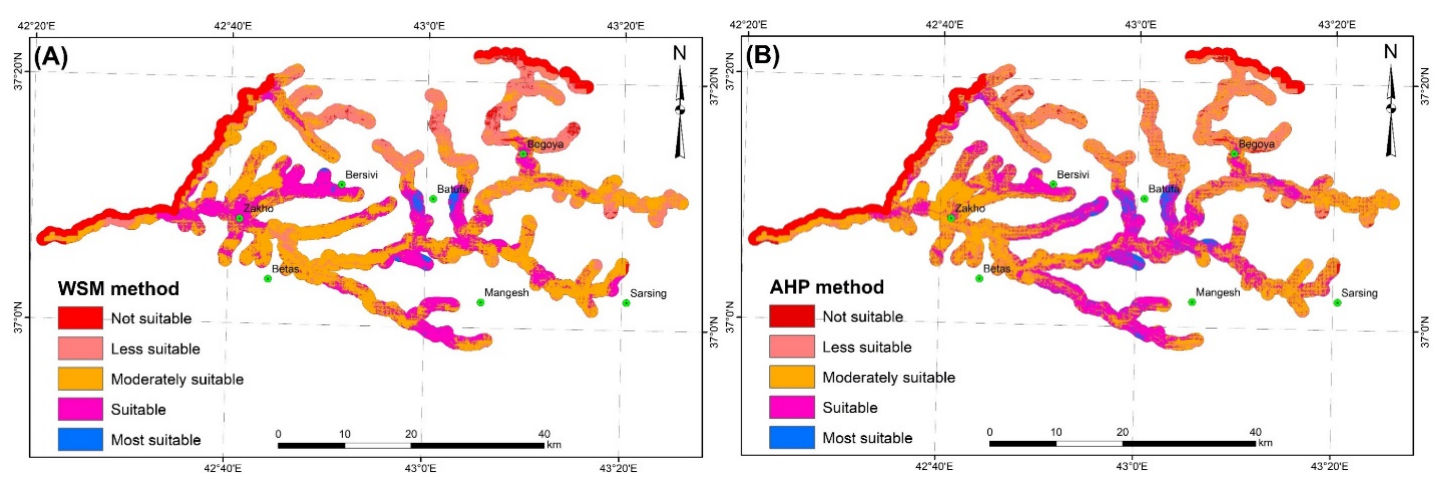

Figure 12. Distribution of suitability maps of dam site using (A) weighted sum method (WSM) and (B) analytic hierarchy process (AHP) with buffer of $1000 \mathrm{~m}$. 


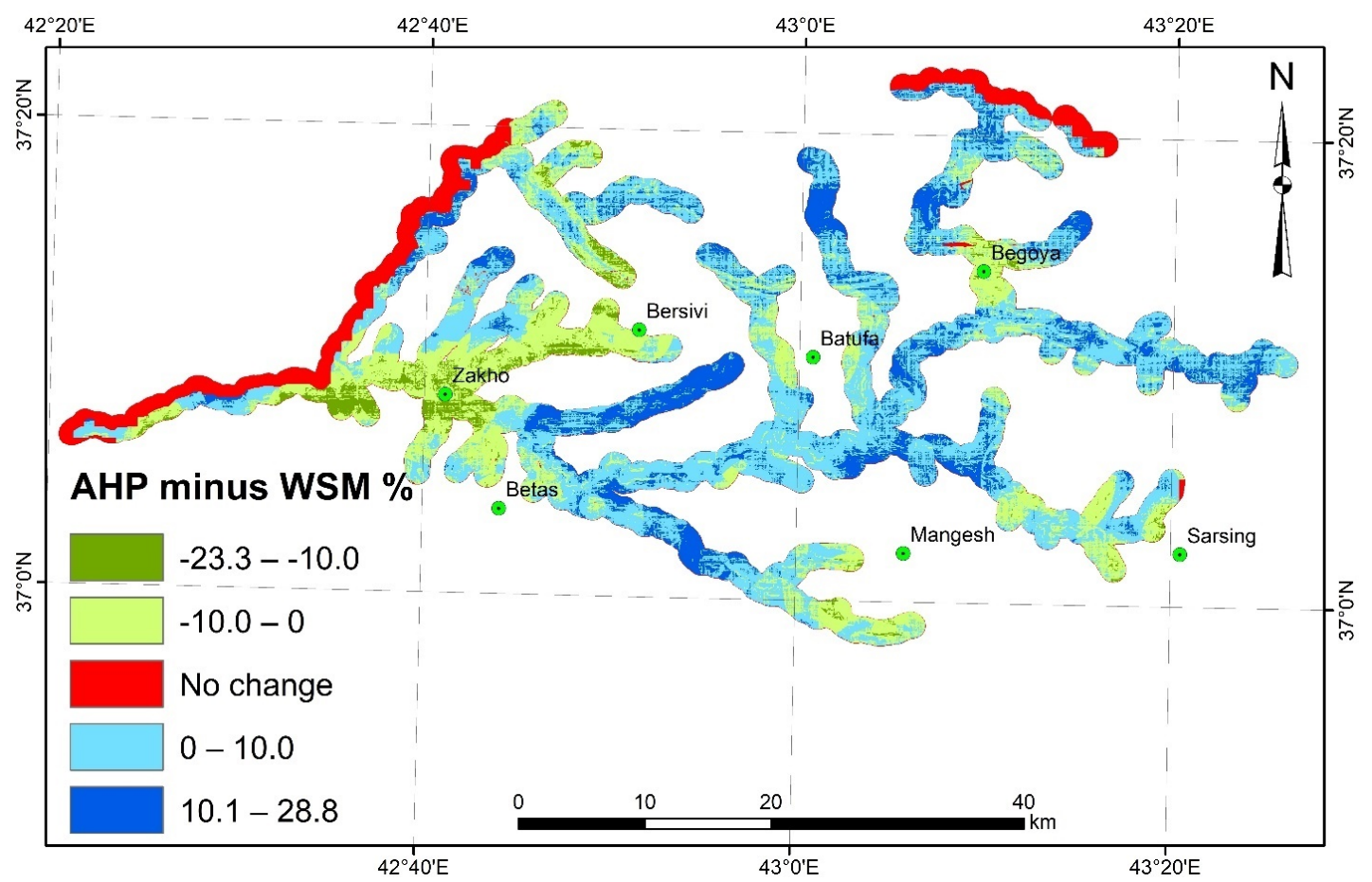

Figure 13. Difference (AHP minus WSM) map.

\subsection{Classification Accuracy of the Two Adopted Models with Previosly Recommended Sites}

Figure 14 shows the accuracy of suitable pixels by number, the accuracy of suitable pixels by weight, and the OA for three buffer zones used (i.e., 250, 500, and $1000 \mathrm{~m}$ ), which are described in Table A4 for the two models. The OA is evaluated using the accuracy of suitable pixels by number, and the accuracy of suitable pixels by weight.

The average of OA for the AHP model is higher than the OA for WSM, 58.27 and 52.78, respectively. The AHP model shows that the best-planned dams are located at sites labeled number 7,12 , and 21, respectively. However, the WSM model shows that the best-planned dams are at number 21, 16, and 8 . Both WSM and AHP models indicate that the planned dams numbered 1, 4, 6, 9, 10, 15, and 19 are either not suitable or less suitable. In addition, the most unsuitable planned dams are at 15, 9, and 19 (Figure 14, Table A1, and Figure A1).

We applied the threshold operation to the AHP raster, which ranged between 0 and 1 . The suitable selected threshold value for the AHP raster was 0.8. The selection of the threshold values for the AHP raster was determined experimentally. The final thresholded AHP raster included 11 groups of pixels, which were used to generate areas representing suitable dam sites. 

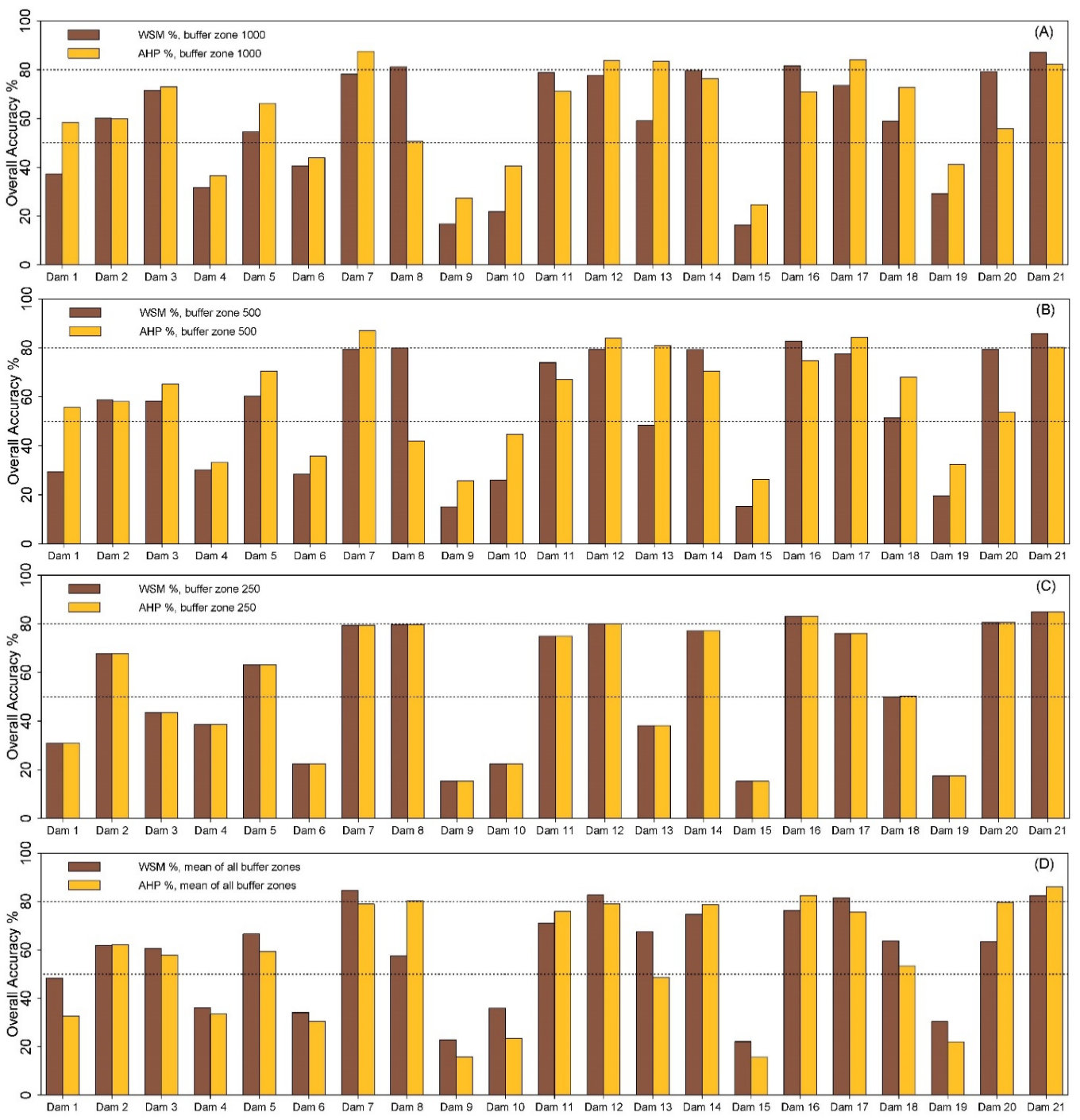

Figure 14. Overall accuracy of the SWM and AHP models of the (A) buffer zone $1000 \mathrm{~m}$, (B) buffer zone $500 \mathrm{~m}$, (C) buffer zone $250 \mathrm{~m}$, and (D) mean of all buffer zones.

\section{Discussion}

Selecting suitable sites using GIS techniques is a complex task due to the influence of many factors that affect the location of dams. Careful consideration of predictive factors is required to adequately assess the weightings of these factors according to specific site conditions. Published literature indicates that dam site selection involves consideration of important variables such as geology, hydrology, slope, runoff, drainage order, environmental, and socioeconomics aspects as effective factors [23]. Almost all of these factors were applied in other areas having similar characteristics of climate, environment, morphology, and geology as the Greater Zab River [14] and Duhok governorate [8] in northern Iraq, and Sistan and Baluchestan provinces of Iran [96]. We used another factor, stream width, as an alternative to discharge measurement beside the above-mentioned factors to improve the value of the methodology used. The discharge can be measured by multiplying the velocity by the width and the average depth of the stream [97]. Due to the lack of gauging stations to measure the discharge, stream width has been used as a factor to select the dam site. To the best of our knowledge, this study is the first one to use stream width as a proxy to stream discharge in a GIS-based application for dam site selection. We believe that measuring stream width using high-resolution imaging is a reliable factor to estimate river discharges. In our opinion, it is much better than other suggested factors, such as stream density [31,92] 
that does not estimate the discharge, and lumps together all drainages in the area regardless of whether they are dry, seasonal, or perennial.

Although the $\mathrm{CN}$ grid is not indicative of runoff, several studies on dam site selection have used it as a predictive factor [9,23,25-28,30,31]. Al-Ruzouq [31] and Mugo [9] used the drainage density as an expression of runoff and considered the $\mathrm{CN}$ grid as a predictive factor. Our study emphasizes combining more than one factor as an expression of runoff.

Noori [14] found an inverse relationship between site suitability and distance to villages, towns, and cities. Sayl [29] determined the distance of selected dam site to villages, towns, and cities to be $250 \mathrm{~m}$. In this study, we used the inverse relation between site suitability and distance to villages, towns, and cities. At the same time, we deemed areas located $<250 \mathrm{~m}$ from villages, towns, and cities as not suitable for dam sites. The closet village and city to the 11 dam sites, are located 485 and $3600 \mathrm{~m}$ away, respectively.

The AHP model is a robust tool for solving decision problems and system analysis as it simplifies complex decisions to a series of pairwise comparisons [98], while the WSM model is a simple multicriteria decision-making approach [99]. The boxplot (Figure 15) of the mean of all buffer zones for the 21 dam sites for each of the WSM and AHP models shows that the AHP method is better than WSM. The suitability of the AHP method is affirmed from the distribution of its weighted factors, which is far above $50 \%$ of the OA (Figure 15; right), as compared to that of WSM that falls close to $50 \%$ (Figure 15; left). Our study confirms the results of Tscheikner-Gratl et al. [100] that the AHP better than WSM. However, it disagrees with Mulliner et al. [34], who stated that WSM was nearly similar to AHP, and Adamczak et al. [101], who concluded that WSM has greater efficiency than AHP.

Different lithologic units influence quality of the reservoir water, dam foundation, reservoir characteristics, and stability of the dam in the event of rapid discharge [99]. Accordingly, the geotechnical constraints of the rock units in the Al-Khabur basin make lithology a major predictive factor (Table A3).

Drought events occur regularly in the Al-Khabur area, due to: lack of rain in the summer, high runoff caused by varied topography, and significant evaporation due to high temperatures. These environmental condition calls for careful planning and proper management of the available water resources. Unlike the Mosul Dam where the unfavorable evaporite beds contribute to active karstification threatening the stability of the dam [17], we have examined areas with favorable geology for dam construction. We excluded sites downstream of Mosul Dam because of similar geology (presence of gypsum and anhydrite beds), and focused on areas upstream of the Mosul Dam, where different rock types are exposed.

Based on this study, 11 sites were determined to be suitable for dam location (Figure A2, Figure 16, and Table 5). Three of these correspond to three of the 21 dams that have been suggested by MAWR. Overall accuracies of the 11 sites range between $76.2 \%$ and $91.8 \%$. The most suitable site coincides with dam number 8 (\#8), located in the southeastern part of the study area, which has the largest reservoir, covering an area of $14.86 \mathrm{~km}^{2}$, and capable of holding $1.182 \mathrm{~km}^{3}$ of water (Table 6). In addition, mean river depth at dam site \#8 is about $80 \mathrm{~m}$, which means lower evaporation, as greater reservoir depth results in slower evaporation rate. No village will be inundated as a result of the construction of this dam. The dam site is located on the Mukdadiyah Formation comprising pebbly sandstone, siltstone, and claystone that generally have favorable engineering properties. The only drawback of this dam site is its length of $1367 \mathrm{~m}$, which would add to construction cost.

Dam site \#9 has the highest mean depth of $87 \mathrm{~m}$, but its reservoir is smaller, while dam site \#6 has the lowest mean depth $(12.5 \mathrm{~m})$ and also the smallest reservoir capacity. Similarly, dam sites \#2, \#3, and \#10 have smaller reservoir capacities (Table 6). Based on these considerations, we have excluded sites \#2,\#3,\#8, \#9, and \#10.

This study identifies suitable locations for dams that should be selected for detailed site investigations prior to construction. Allocating resources on sites that have been found to be more suitable would entail significant cost savings, as opposed to sites having severe limitations. 
These multipurpose dams will provide water for drinking and irrigation, electric power generation, and flood control. Benefits would include economic development of the country, including higher crop yield and increased power generation capacity for Iraq, that currently suffers from a critical shortage of electric power. Additionally, it would prevent flooding events that are common in parts of the study area.

The criteria used for dam site selection by the MAWR were based on superficial field surveys and cursory GIS analysis that lacked scientific information. Critical data, such as stream and river discharge, basin size and storage capacity, geology of dam foundation and reservoir area, and related local and regional geotechnical characteristics, were not taken into account. This study was designed to include all key factors (Table 1) to identify suitable dam and safe sites.

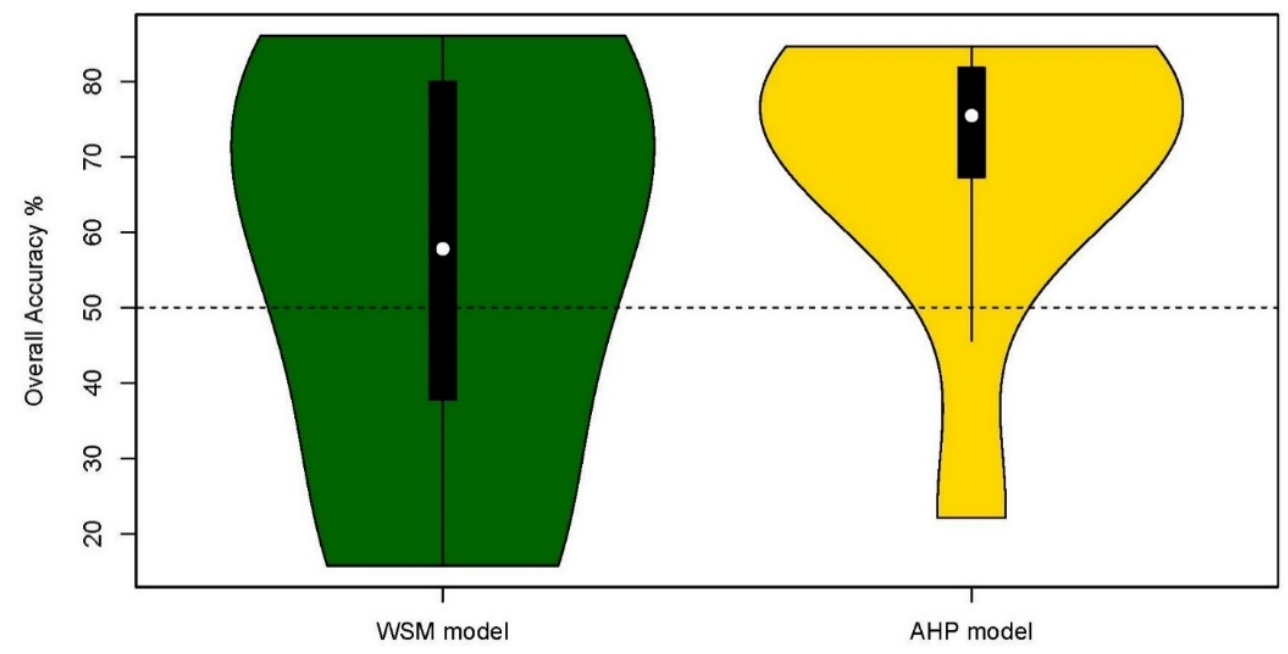

Figure 15. Overall accuracy using the mean of all buffer zones for the 21 dam sites for each of SWM and AHP models.

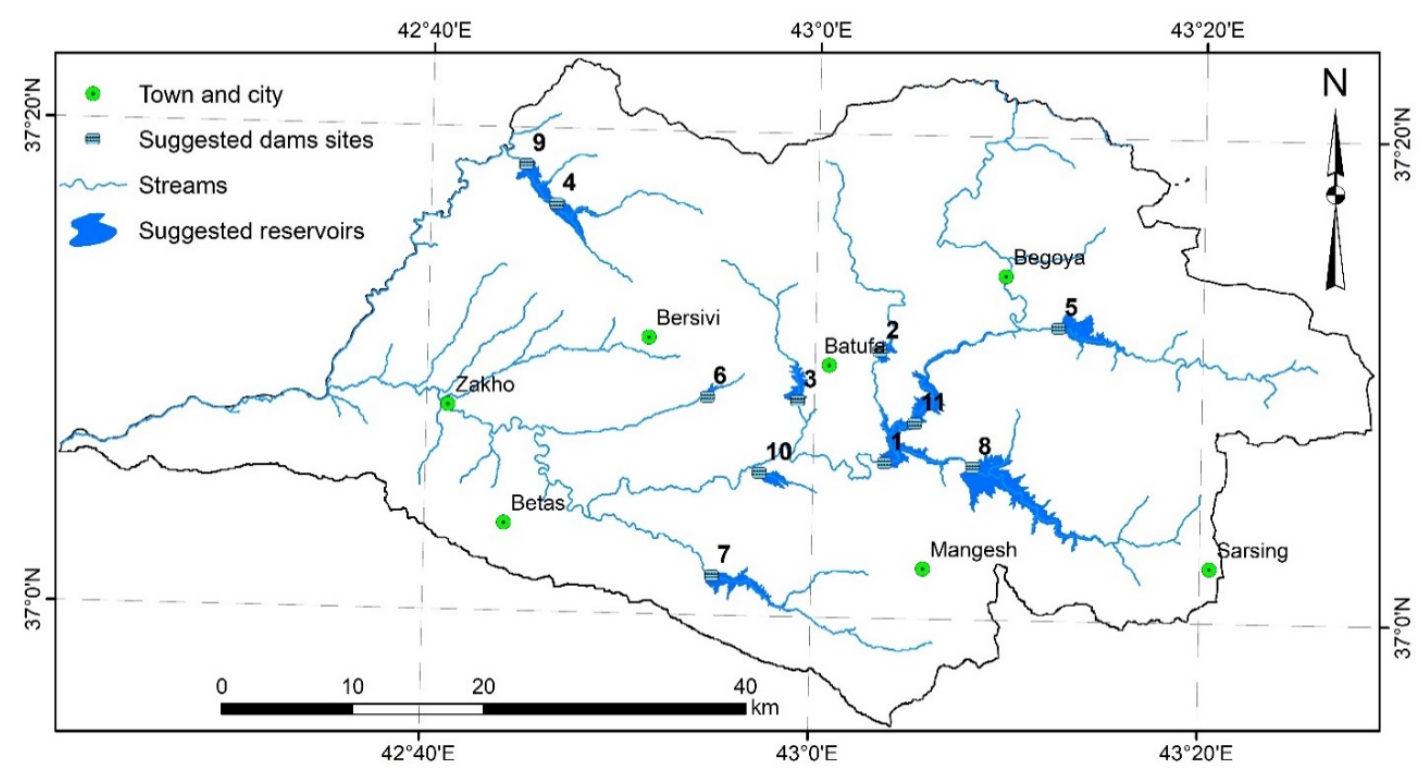

Figure 16. Suggested dam sites based on AHP and WSM models. 
Table 5. Suggested dam's coordinates, the accuracy of the suitable pixels by number (AS), the accuracy of the suitable pixel by weight (AW), and the overall accuracy (OA) of dam site suggested using AHP model.

\begin{tabular}{cccccccccccc}
\hline Dam & \multicolumn{2}{c}{ Coordinates } & \multicolumn{3}{c}{ Buffer 100 } & \multicolumn{3}{c}{ Buffer 500 } & \multicolumn{3}{c}{ Buffer 250 } \\
\hline No. & X & Y & As & Aw & OA & As & Aw & OA & As & Aw & OA \\
\hline 1 & 43.061066 & 37.10736 & 99.7 & 69.7 & 84.7 & 99.7 & 69.4 & 84.5 & 99.6 & 70.1 & 84.8 \\
2 & 43.05568 & 37.18427 & 100 & 81.5 & 90.8 & 100 & 83.5 & 91.8 & 100 & 82.8 & 91.4 \\
3 & 42.98572 & 37.14923 & 100 & 79.6 & 89.8 & 100 & 80.7 & 90.4 & 100 & 81.2 & 90.6 \\
4 & 42.774496 & 37.28125 & 93.5 & 66.6 & 80.1 & 94.5 & 68.8 & 81.7 & 100 & 72.2 & 86.1 \\
5 & 43.208654 & 37.20219 & 89.7 & 65.1 & 77.4 & 92.2 & 67.1 & 79.7 & 100 & 69.2 & 84.6 \\
6 & 42.907832 & 37.15043 & 100 & 73.5 & 86.8 & 100 & 74.9 & 87.5 & 100 & 74.6 & 87.3 \\
7 & 42.914868 & 37.02736 & 99.4 & 67.7 & 83.6 & 98.5 & 67.7 & 83.1 & 97.3 & 68.4 & 82.8 \\
8 & 43.136919 & 37.10535 & 95.9 & 69 & 82.4 & 99.3 & 72.8 & 86.1 & 99.1 & 72.2 & 85.6 \\
9 & 42.747988 & 37.30821 & 91.5 & 63.5 & 77.5 & 89.2 & 63.2 & 76.2 & 100 & 60 & 80 \\
10 & 42.953957 & 37.09876 & 99.1 & 68.3 & 83.7 & 98.1 & 68.7 & 83.4 & 96.8 & 66.7 & 81.7 \\
11 & 43.08669 & 37.13489 & 99.6 & 68.3 & 83.9 & 100 & 71 & 85.5 & 100 & 73.7 & 86.9 \\
\hline
\end{tabular}

Table 6. Characteristics of the suggested dam sites.

\begin{tabular}{|c|c|c|c|c|c|c|c|c|c|c|c|c|}
\hline \multirow{2}{*}{$\begin{array}{l}\text { Dam } \\
\text { No. }\end{array}$} & \multirow{2}{*}{$\begin{array}{c}\text { Dam } \\
\text { Width (m) }\end{array}$} & \multirow{2}{*}{$\begin{array}{c}\text { Lake Area } \\
\left(\mathrm{km}^{2}\right)\end{array}$} & \multirow{2}{*}{ Volume $\left(\mathrm{m}^{3}\right)$} & \multicolumn{3}{|c|}{ Depth (m) } & \multirow{2}{*}{$\begin{array}{c}\text { Basin Area } \\
\left(\mathbf{k m}^{2}\right)\end{array}$} & \multicolumn{4}{|c|}{ Dam Profile } & \multirow{2}{*}{$\mathbf{N}_{\mathrm{v}}$} \\
\hline & & & & Mean & Min & Max & & X Start & Y Start & $X$ End & Y End & \\
\hline 1 & 1109.9 & 8.61 & $226,654,026$ & 26.33 & 624 & 670 & 2420.5 & 327929 & 4108249 & 327382 & 4109214 & 8 \\
\hline 2 & 509.6 & 1.31 & $37,026,508$ & 28.31 & 732 & 783 & 103.8 & 327516 & 4116203 & 327218 & 4116616 & 1 \\
\hline 3 & 850 & 2.35 & $53,640,739$ & 22.8 & 648 & 723 & 74.3 & 321553 & 4113344 & 320703 & 4113308 & 4 \\
\hline 4 & 1069 & 3.44 & $274,350,307$ & 79.85 & 716 & 845 & 149.7 & 303129 & 4128682 & 302214 & 4128066 & 1 \\
\hline 5 & 667 & 5.34 & $421,706,403$ & 78.91 & 748 & 864 & 266.9 & 340979 & 4118449 & 341072 & 4119110 & 2 \\
\hline 6 & 443 & 0.46 & $5,769,178$ & 12.57 & 606 & 627 & 26.3 & 314325 & 4113532 & 313951 & 4113768 & 0 \\
\hline 7 & 817 & 4.39 & $191,423,581$ & 43.58 & 604 & 668 & 219.9 & 314213 & 4099620 & 314786 & 4100203 & 1 \\
\hline 8 & 1367 & 14.86 & $1,182,091,212$ & 79.53 & 677 & 788 & 276.9 & 333616 & 4107771 & 334842 & 4108377 & 0 \\
\hline 9 & 1148 & 3.93 & $341,654,356$ & 86.99 & 626 & 751 & 184 & 299868 & 4131249 & 300953 & 4131627 & 1 \\
\hline 10 & 372 & 1.6 & $55,823,171$ & 34.97 & 579 & 631 & 35.6 & 318013 & 4107669 & 318314 & 4107887 & 0 \\
\hline 11 & 737 & 6.04 & $199,256,701$ & 32.97 & 648 & 706 & 1963.5 & 330258 & 4111289 & 329802 & 4111868 & 3 \\
\hline
\end{tabular}

In Table $6, \mathrm{~N}_{\mathrm{V}}$ is the number of villages that will be inundated.

\section{Conclusions}

This study serves as a good example of integration of remote sensing images, GIS, and geotechnics in water resources development. We used both AHP and WSM methods for selecting the most suitable locations for dams. Fourteen major factors in dam site suitability analyses were generated from various remote sensing and ancillary data. For the first time, this study used the stream width, measured from high-resolution images instead of the river discharge measurements, as a predictive factor for dam site selection. Twenty-one dam sites, proposed by MAWR, were used as reference sites. We also evaluated the accuracy of the AHP and WSM techniques. For all 21 dams, the overall accuracy of the AHP method was found to be greater than the WSM. Eleven dam sites were found suitable for potential runoff harvesting. Three of these 11 sites correspond to the dam sites that have been suggested by the MAWR. For both models, the accuracy of the 11 sites ranged between $76.2 \%$ and $91.8 \%$. The difference between AHP and WSM map shows that the suitability is higher in almost all the pixels that are present in the AHP model, while a few pixels show the opposite. This study offers a useful and inexpensive tool to decision-makers for preliminary screening of potential dam sites, eliminating sites with severe limitations, and directing geotechnical exploration activities at sites with minimum limitations. This method can be applied for the rest of the hydrological basins in the Kurdistan region.

Based on these analyses, 11 dam sites were determined to be more suitable. However, 10 sites, numbers 1, 4, 5, 6 and 15, 16, 17, 18, and 19, that are located in the Al-Khabur River basin, should be avoided because of heavy solutioning activities and faster reservoir siltation rates. Site \#8 appeared most suitable for dam location because of its large reservoir capacity, low evaporation rate, and no villages within its reservoir. 
It must be emphasized that this study should not be used for selecting the final site without conducting detailed on-site geotechnical investigations at the suggested locations. Nonetheless, by eliminating sites with serious geological and other constraints, the study has identified sites that appear more suitable where additional exploration should be carried out for design and construction of the dam.

Author Contributions: Arsalan Ahmed Othman prepared and processed the data and performed the study. He also wrote the manuscript and outlined the research. Ahmed F. Al-Maamar and Veraldo Liesenberg supported the analysis and discussion. Diary Ali Mohammed Amin Al-Manmi assisted with the validation of the results and the writing. Ayad M. Fadhil Al-Quraishi, Syed E. Hasan and Ahmed K. Obaid supported the writing and discussion. All authors have checked and approved the manuscript.

Funding: Veraldo Liesenberg is supported by FAPESC (2017TR1762) and CNPq (313887/2018-7).

Acknowledgments: We thank USGS for providing Landsat and DEM data. We are grateful to the General Survey Authority and Ministry of Planning, Iraq, for providing the data. We would like to thank Saffa F. A. Fouad, the Director General of Iraq Geological Survey, for his tremendous support and encouragement.

Conflicts of Interest: The authors declare no conflict of interest. 


\section{Appendix A}

Table A1. Proposed sites of dams in the study area [16].

\begin{tabular}{|c|c|c|c|c|c|c|c|c|c|c|}
\hline No. & Site Name & River order Stream & Latitude & Longitude & Main Purpose & Type of Project & $\begin{array}{c}\text { Priority } \\
\text { Status }\end{array}$ & $\begin{array}{l}\text { Catchment } \\
\text { Area }\left(\mathrm{km}^{2}\right)\end{array}$ & $\begin{array}{c}\text { Dam Height } \\
(\mathrm{m})\end{array}$ & $\begin{array}{c}\text { Storage Capacity } \\
\left(\text { million } \mathrm{m}^{3}\right)\end{array}$ \\
\hline 1 & Base & Khabur (1) & 37.1713 & 43.0946 & Irrigation/Energy & Multi-Purpose dam & First & 1962 & 75 & 101 \\
\hline 2 & Sbna2 & Sibna (2) & 37.0589 & 43.2306 & Irrigation/Energy & Agriculture reservoir & First & 138.42 & 38 & 5.95 \\
\hline 3 & Parzoor & Jalal Barzoor (2) & 37.2114 & 42.7036 & Irrigation & Agriculture reservoir & First & 14.6 & 28 & 1.6 \\
\hline 4 & Khizawa & Khabur (1) & 37.2055 & 42.9689 & Irrigation/Energy & Agriculture reservoir & Second & 46.85 & 34 & 2.8 \\
\hline 5 & Zakho & Khabur (1) & 37.072 & 42.8018 & Irrigation/Energy & Agriculture reservoir & Second & 3366.82 & 18 & 17.1 \\
\hline 6 & Barkawar & Khabur (1) & 37.0838 & 42.7894 & Irrigation/Energy & Agriculture reservoir & Second & 3380.93 & 13 & 4.3 \\
\hline 7 & Khuk-sindi & Divro (2) & 37.165 & 42.9384 & Irrigation & Agriculture reservoir & Second & 11.6 & 16 & 1.2 \\
\hline 8 & Bakirman & Unk (2) & 37.1353 & 42.5923 & Irrigation & Agriculture reservoir & Second & 9.12 & 16 & 1 \\
\hline 9 & Kunduk & Shiv a Basagha (4) & 37.2797 & 42.8938 & Irrigation & Agriculture reservoir & Second & 36.95 & 30 & 2 \\
\hline 10 & Suria & Av-a Zariza (2) & 37.2238 & 43.0755 & Irrigation/Energy & Agriculture reservoir & Third & 83 & 22 & 5 \\
\hline 11 & Daldal & Mangesh (3) & 37.0309 & 43.0423 & Irrigation & Agriculture reservoir & Third & 35.6 & 17 & 1.8 \\
\hline 12 & Chiran & Rogarm (2) & 37.0244 & 42.936 & Irrigation/Energy & Agriculture reservoir & Third & 206 & 26 & 9 \\
\hline 13 & Navkandalak & Divro (2) & 37.1399 & 42.8776 & Irrigation/Energy & Agriculture reservoir & Third & 48.4 & 25 & 3 \\
\hline 14 & Darjalal & Shiv-a Jalal (2) & 37.2114 & 42.7514 & Irrigation & Agriculture reservoir & Third & 16.5 & 13 & 0.6 \\
\hline 15 & Begova & Khabur (1) & 37.26 & 43.133 & Irrigation/Energy & $\begin{array}{l}\text { Multi-Purpose dam, } \\
\text { limited storage }\end{array}$ & Fourth & 1495 & 85 & 169 \\
\hline 16 & Jamik-Chalki & Khabur (1) & 37.2383 & 43.169 & Energy & $\begin{array}{l}\text { Run-of-river } \\
\text { hydropower }\end{array}$ & Fourth & 1584.24 & 48 & 40 \\
\hline 17 & Kovky & Khabur (1) & 37.1075 & 43.061 & Energy & $\begin{array}{l}\text { Run-of-river } \\
\text { hydropower }\end{array}$ & Fourth & 2430.3 & 19 & 14 \\
\hline 18 & Bajla & Khabur (1) & 37.0947 & 42.912 & Irrigation/Energy & $\begin{array}{l}\text { Run-of-river } \\
\text { hydropower }\end{array}$ & Fourth & 2646.21 & 41 & 104.6 \\
\hline 19 & Khwalish & Khabur (1) & 37.099 & 42.7739 & Energy & $\begin{array}{l}\text { Run-of-river } \\
\text { hydropower }\end{array}$ & Fourth & 3406.23 & 24 & 10 \\
\hline 20 & Cham Sermo & Khabur (1) & 37.1317 & 42.703 & Energy & $\begin{array}{l}\text { Run-of-river } \\
\text { hydropower }\end{array}$ & Fourth & 3184.59 & 20 & 26.2 \\
\hline 21 & Darkar Ajam & Seasonal stream (3) & 37.2036 & 42.827 & Irrigation & Agriculture reservoir & $\begin{array}{c}\text { Existing } \\
\text { dam }\end{array}$ & 4.42 & 15 & 0.15 \\
\hline
\end{tabular}


Table A2. Rate of the selected factors used for dam site selection in the KhRB versus all factors used elsewhere.

\begin{tabular}{|c|c|c|c|c|c|c|c|c|c|c|c|c|c|c|c|c|c|c|c|c|c|}
\hline \multirow[b]{2}{*}{ Reference } & \multirow[b]{2}{*}{ 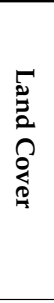 } & \multirow[b]{2}{*}{$\stackrel{n}{\varrho}$} & \multirow[b]{2}{*}{$\begin{array}{l}0 \\
\frac{0}{0} \\
0 \\
0 \\
0 \\
0 \\
0 \\
0 \\
0\end{array}$} & \multirow[b]{2}{*}{ 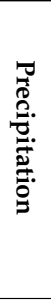 } & \multirow[b]{2}{*}{ 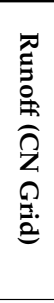 } & \multirow[b]{2}{*}{$\begin{array}{l}\frac{\pi}{0} \\
\frac{0}{4} \\
\stackrel{0}{0} \\
\frac{0}{9}\end{array}$} & \multirow[b]{2}{*}{ 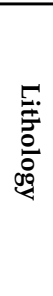 } & \multirow[b]{2}{*}{ 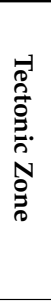 } & \multirow[b]{2}{*}{ 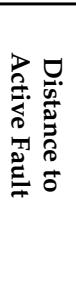 } & \multirow{2}{*}{ 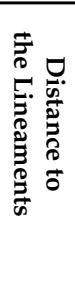 } & \multirow[b]{2}{*}{ 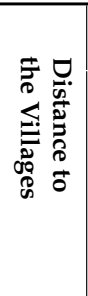 } & \multirow[b]{2}{*}{ 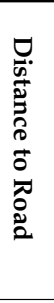 } & \multirow{2}{*}{ 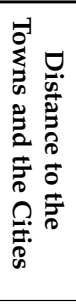 } & \multicolumn{3}{|c|}{ Discharge } & \multirow[b]{2}{*}{ 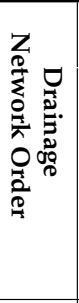 } & \multirow{2}{*}{ 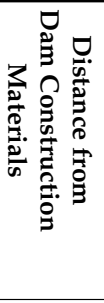 } & \multirow{2}{*}{ 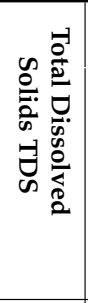 } & \multirow[b]{2}{*}{ 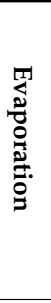 } & \multirow[b]{2}{*}{ 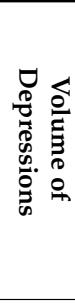 } \\
\hline & & & & & & & & & & & & & & 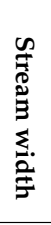 & 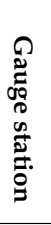 & 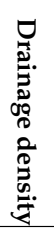 & & & & & \\
\hline [14] & $*$ & $*$ & * & $*$ & & & $*$ & $*$ & * & & * & $*$ & * & & $*$ & & & * & & & \\
\hline [23] & $*$ & * & $*$ & * & ${ }^{*}$ & & & & & $*$ & & & & & & & $*$ & & & & \\
\hline$[24]$ & $*$ & $*$ & $*$ & $*$ & & & & & & & & & & & & & $*$ & & & & \\
\hline [25] & $*$ & $*$ & & & $*$ & $*$ & & & & & & & & & & & $*$ & & & & $*$ \\
\hline [26] & $*$ & $*$ & ${ }^{*}$ & $*$ & ${ }^{*}$ & & & & & & & & & & & & & & & & \\
\hline [27] & $*$ & $*$ & & & ${ }^{*}$ & * & & & & & & & & & & & & & & & \\
\hline [28] & $*$ & $*$ & $*$ & $*$ & $*$ & & & & & & & & & & & & & & & & \\
\hline [29] & $*$ & $*$ & $*$ & * & & & $*$ & $*$ & $*$ & & * & $*$ & & & & & & & & $*$ & \\
\hline [30] & $*$ & ${ }^{*}$ & $*$ & $*$ & $*$ & $*$ & & & & $*$ & $*$ & & * & & & & $*$ & & & & \\
\hline [31] & & & * & * & ${ }^{*}$ & $*$ & ${ }^{*}$ & $*$ & $*$ & $*$ & & & & & & $*$ & $*$ & & $*$ & & \\
\hline \multirow{2}{*}{$\begin{array}{l}\text { Rate of use } \\
\text { the factor \% }\end{array}$} & \multirow[t]{2}{*}{90} & \multirow[t]{2}{*}{90} & \multirow[t]{2}{*}{80} & \multirow[t]{2}{*}{80} & \multirow[t]{2}{*}{70} & \multirow[t]{2}{*}{40} & \multirow[t]{2}{*}{30} & \multirow[t]{2}{*}{30} & \multirow[t]{2}{*}{30} & \multirow[t]{2}{*}{30} & 30 & 20 & 20 & 0 & 10 & 10 & 50 & 10 & 10 & 10 & 10 \\
\hline & & & & & & & & & & & & & & & 20 & & & & & & \\
\hline
\end{tabular}


Table A3. Decision rules for used factors and finalized weights of criteria obtained from WSM and AHP method.

\begin{tabular}{|c|c|c|c|c|c|c|c|c|c|c|c|}
\hline Factor/Subfactor & Suitability & Rank & $\begin{array}{c}\text { Factor } \\
\text { Weight }\end{array}$ & $\begin{array}{l}\text { Normalized } \\
\text { AHP Rank }\end{array}$ & $\begin{array}{l}\text { Normalized } \\
\text { SWM Rank }\end{array}$ & Factor/Sub-Factor & Suitability & Rank & $\begin{array}{c}\text { Factor } \\
\text { Weight }\end{array}$ & $\begin{array}{l}\text { Normalized } \\
\text { AHP Rank }\end{array}$ & $\begin{array}{l}\text { Normalized } \\
\text { SWM Rank }\end{array}$ \\
\hline 1. Lithology & & & & & & Orchard or tree farm & Suitable & 7 & 3 & 1.024 & 1.683 \\
\hline Lake and River & Not suitable & 1 & 9 & 0.439 & 0.240 & $\begin{array}{l}\text { Mountain brush mixture of } \\
\text { oak brush }\end{array}$ & Suitable & 7 & 3 & 1.024 & 1.683 \\
\hline Flood Plain & Not suitable & 1 & 9 & 0.439 & 0.240 & Water & Most suitable & 9 & 3 & 1.317 & 2.163 \\
\hline Slope & Not suitable & 1 & 9 & 0.439 & 0.240 & Cultivated land or bare land & Suitable & 7 & 3 & 1.024 & 1.683 \\
\hline Residual Soil & Not suitable & 1 & 9 & 0.439 & 0.240 & 7. Elevation (m) & & & & & \\
\hline Bai Hassan & Less suitable & 3 & 9 & 1.317 & 0.721 & $<500$ & Not suitable & 1 & 5 & 0.244 & 0.240 \\
\hline Mukdadiyah & Not suitable & 1 & 9 & 0.439 & 0.240 & $500-600$ & Less suitable & 3 & 5 & 0.732 & 0.721 \\
\hline Injana & Moderately suitable & 5 & 9 & 2.195 & 1.202 & $600-700$ & Suitable & 7 & 5 & 1.707 & 1.683 \\
\hline Fatha & Not suitable & 1 & 9 & 0.439 & 0.240 & $700-800$ & Most suitable & 9 & 5 & 2.195 & 2.163 \\
\hline Pilaspi & Suitable & 7 & 9 & 3.073 & 1.683 & $800-900$ & Moderately suitable & 5 & 5 & 1.220 & 1.202 \\
\hline Kolosh & Not suitable & 1 & 9 & 0.439 & 0.240 & 900-1000 & Less suitable & 3 & 5 & 0.732 & 0.721 \\
\hline Shiranish & Less suitable & 3 & 9 & 1.317 & 0.721 & $>1000$ & Not suitable & 1 & 5 & 0.244 & 0.240 \\
\hline Aqra-Bekhme & Most suitable & 9 & 9 & 3.951 & 2.163 & 8. Slope $\left(^{\circ}\right)$ & & & & & \\
\hline Mergi & Moderately suitable & 5 & 9 & 2.195 & 1.202 & $0-2$ & Most suitable & 9 & 7 & 3.073 & 2.164 \\
\hline Qamchuqa & Suitable & 7 & 9 & 3.073 & 1.683 & $2-10$ & Suitable & 7 & 7 & 2.390 & 1.682 \\
\hline Garagu & Suitable & 7 & 9 & 3.073 & 1.683 & $10-20$ & Moderately suitable & 5 & 7 & 1.707 & 1.202 \\
\hline Sarmord & Suitable & 7 & 9 & 3.073 & 1.683 & $20-30$ & Less suitable & 3 & 7 & 1.024 & 0.721 \\
\hline $\begin{array}{l}\text { Chia Gara, Barsarin, } \\
\text { Naokelekan, Sargelu }\end{array}$ & Less suitable & 3 & 9 & 1.317 & 0.721 & $>30$ & Not suitable & 1 & 7 & 0.342 & 0.240 \\
\hline Sehkaniyan \& Sarki & Moderately suitable & 5 & 9 & 2.195 & 1.202 & 9. Precipitation $(\mathrm{mm} / \mathrm{yr})$ & & & & & \\
\hline Kura China \& Baluti & Suitable & 7 & 9 & 3.073 & 1.683 & $<630$ & Not suitable & 1 & 5 & 0.244 & 0.240 \\
\hline Geli Khane & Suitable & 7 & 9 & 3.073 & 1.683 & $630-665$ & Less suitable & 3 & 5 & 0.732 & 0.721 \\
\hline Beduh & Not suitable & 1 & 9 & 0.439 & 0.240 & $665-700$ & Moderately suitable & 5 & 5 & 1.220 & 1.202 \\
\hline Mirga Mir & Less suitable & 3 & 9 & 1.317 & 0.721 & $700-730$ & Suitable & 7 & 5 & 1.707 & 1.683 \\
\hline Chia Zairi & Not suitable & 1 & 9 & 0.439 & 0.240 & $>730$ & Most suitable & 9 & 5 & 2.195 & 2.164 \\
\hline Harur & Less suitable & 3 & 9 & 1.317 & 0.721 & 10. Stream width $(\mathrm{m})$ & & & & & \\
\hline Ora & Not suitable & 1 & 9 & 0.439 & 0.240 & $<0.6$ & Not suitable & 1 & 7 & 0.342 & 0.240 \\
\hline Kaista & Less suitable & 3 & 9 & 1.317 & 0.721 & $0.6-1$ & Less suitable & 3 & 7 & 1.024 & 0.721 \\
\hline Khabour & Not suitable & 1 & 9 & 0.439 & 0.240 & $1-2$ & Moderately suitable & 5 & 7 & 1.707 & 1.202 \\
\hline
\end{tabular}


Table A3. Cont.

\begin{tabular}{|c|c|c|c|c|c|c|c|c|c|c|c|c|}
\hline Factor/Subfactor & Suitability & Rank & $\begin{array}{c}\text { Factor } \\
\text { Weight }\end{array}$ & $\begin{array}{l}\text { Normalized } \\
\text { AHP Rank }\end{array}$ & $\begin{array}{l}\text { Normalized } \\
\text { SWM Rank }\end{array}$ & & Factor/Sub-Factor & Suitability & Rank & $\begin{array}{c}\text { Factor } \\
\text { Weight }\end{array}$ & $\begin{array}{l}\text { Normalized } \\
\text { AHP Rank }\end{array}$ & $\begin{array}{l}\text { Normalized } \\
\text { SWM Rank }\end{array}$ \\
\hline 2. Tectonic zones & & & & & & & $2-10$ & Suitable & 7 & 7 & 2.390 & 1.683 \\
\hline Imbricated Zone & Less suitable & 3 & 1 & 0.146 & 0.721 & & $>10$ & Most suitable & 9 & 7 & 3.073 & 2.164 \\
\hline High Folded Zone & Moderately suitable & 5 & 1 & 0.244 & 1.202 & 11. & Curve Number (CN) & & & & & \\
\hline 3. Distance to the active & ult (m) & & & & & & $>31$ & Not suitable & 1 & 5 & 0.244 & 0.240 \\
\hline $0-1000$ & Not suitable & 1 & 3 & 0.146 & 0.240 & & $31-68$ & Less suitable & 3 & 5 & 0.732 & 0.721 \\
\hline $1000-2000$ & Less suitable & 3 & 3 & 0.439 & 0.721 & & $68-80$ & Moderately suitable & 5 & 5 & 1.220 & 1.202 \\
\hline $2000-5000$ & Moderately suitable & 5 & 3 & 0.732 & 1.202 & & $80-87$ & Suitable & 7 & 5 & 1.707 & 1.683 \\
\hline $5000-10,000$ & Suitable & 7 & 3 & 1.024 & 1.683 & & $>87$ & Most suitable & 9 & 5 & 2.195 & 2.164 \\
\hline$>10,000$ & Most suitable & 9 & 3 & 1.317 & 2.163 & 12. & Distance to the road (m) & & & & & \\
\hline 4. Distance to the lineam & ts $(\mathrm{m})$ & & & & & & $<1000$ & Most suitable & 9 & 1 & 0.439 & 2.164 \\
\hline $0-500$ & Not suitable & 1 & 3 & 0.146 & 0.240 & & $1000-2500$ & Suitable & 7 & 1 & 0.342 & 1.683 \\
\hline $500-1000$ & Less suitable & 3 & 3 & 0.439 & 0.721 & & $2500-5000$ & Moderately suitable & 5 & 1 & 0.244 & 1.202 \\
\hline $1000-2000$ & Moderately suitable & 5 & 3 & 0.732 & 1.202 & & $5000-7500$ & Less suitable & 3 & 1 & 0.146 & 0.721 \\
\hline $2000-3000$ & Suitable & 7 & 3 & 1.024 & 1.683 & & $>7500$ & Not suitable & 1 & 1 & 0.049 & 0.240 \\
\hline$>3000$ & Most suitable & 9 & 3 & 1.317 & 2.163 & 13. & Distance to the towns and & $\mathrm{d}$ cities $(\mathrm{m})$ & & & & \\
\hline 5. Soil type & & & & & & & $250-2500$ & Most suitable & 9 & 1 & 0.439 & 2.164 \\
\hline $\begin{array}{l}\text { Lithosols and Eutric } \\
\text { Cambisols }\end{array}$ & Not suitable & 1 & 5 & 0.244 & 0.240 & & $2500-5000$ & Suitable & 7 & 1 & 0.342 & 1.683 \\
\hline $\begin{array}{l}\text { Lithosols, Rendzinas, and } \\
\text { Calcic Xerosols }\end{array}$ & Not suitable & 1 & 5 & 0.244 & 0.240 & & $5000-10,000$ & Moderately suitable & 5 & 1 & 0.244 & 1.202 \\
\hline $\begin{array}{l}\text { Lithosols, Calcaric Regoso, } \\
\text { and Calcic Xerosols }\end{array}$ & Not suitable & 1 & 5 & 0.244 & 0.240 & & $10,000-12,500$ & Less suitable & 3 & 1 & 0.146 & 0.721 \\
\hline $\begin{array}{l}\text { Chromic Luvisols, Calcic } \\
\text { Cambisols, Lithosols,\& } \\
\text { Calcaric Regoso }\end{array}$ & Moderately suitable & 5 & 5 & 1.220 & 1.202 & & $>12,500$ and $0-250$ & Not suitable & 1 & 1 & 0.049 & 0.240 \\
\hline $\begin{array}{l}\text { Chromic Vertisols, and } \\
\text { Calcic Xerosols }\end{array}$ & Most suitable & 9 & 5 & 2.195 & 2.163 & 14. & Distance to the villages ( $\mathrm{m}$ & & & & & \\
\hline $\begin{array}{c}\text { Calcic Xerosols, } \\
\text { Rendzinas, and Chromic } \\
\text { Vertisols }\end{array}$ & Less suitable & 3 & 5 & 0.732 & 0.721 & & $250-1000$ & Most suitable & 9 & 1 & 0.439 & 2.164 \\
\hline 6. Land cover & & & & & & & $1000-1500$ & Suitable & 7 & 1 & 0.342 & 1.683 \\
\hline Built-up & Not suitable & 1 & 3 & 0.146 & 0.240 & & 1500-2000 & Moderately suitable & 5 & 1 & 0.244 & 1.202 \\
\hline Bare land & Suitable & 7 & 3 & 1.024 & 1.683 & & $2000-3000$ & Less suitable & 3 & 1 & 0.146 & 0.721 \\
\hline Road & Not suitable & 1 & 3 & 0.146 & 0.240 & & $>3000$ and $0-250$ & Not suitable & 1 & 1 & 0.049 & 0.240 \\
\hline
\end{tabular}


Table A4. The overall accuracy of dam site selection using WSM and AHP models.

\begin{tabular}{|c|c|c|c|c|c|c|c|c|c|c|c|c|c|c|c|c|c|c|c|c|c|c|}
\hline & Dam Number & 1 & 2 & 3 & 4 & 5 & 6 & 7 & 8 & 9 & 10 & 11 & 12 & 13 & 14 & 15 & 16 & 17 & 18 & 19 & 20 & 21 \\
\hline \multirow{9}{*}{ 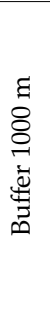 } & $\mathrm{Np}$ & 3492 & 3501 & 3485 & 3496 & 3500 & 3483 & 3489 & 3493 & 3493 & 3491 & 3486 & 3503 & 3490 & 3500 & 3487 & 3493 & 3489 & 3484 & 3495 & 3486 & 3501 \\
\hline & Sp (WSM) & 1075 & 2361 & 3056 & 754 & 2072 & 1205 & 3396 & 3493 & 40 & 181 & 3300 & 3385 & 2238 & 3450 & 133 & 3452 & 3076 & 2291 & 565 & 3385 & 3501 \\
\hline & $\mathrm{Sp}$ (AHP) & 2178 & 2338 & 3092 & 1059 & 2682 & 1369 & 3489 & 1820 & 579 & 1257 & 2852 & 3476 & 3468 & 3246 & 431 & 2897 & 3480 & 3072 & 1240 & 2106 & 3446 \\
\hline & As (WSM) & 30.78 & 67.44 & 87.69 & 21.57 & 59.20 & 34.60 & 97.33 & 100.00 & 1.15 & 5.18 & 94.66 & 96.63 & 64.13 & 98.57 & 3.81 & 98.83 & 88.16 & 65.76 & 16.17 & 97.10 & 100.00 \\
\hline & As (AHP) & 62.37 & 66.78 & 88.72 & 30.29 & 76.63 & 39.31 & 100.00 & 52.10 & 16.58 & 36.01 & 81.81 & 99.23 & 99.37 & 92.74 & 12.36 & 82.94 & 99.74 & 88.17 & 35.48 & 60.41 & 98.43 \\
\hline & Aw (WSM) & 54.43 & 53.06 & 57.22 & 42.94 & 55.72 & 48.52 & 75.23 & 49.22 & 38.21 & 45.02 & 60.42 & 68.48 & 67.49 & 59.96 & 37.07 & 59.11 & 68.40 & 57.45 & 46.82 & 51.26 & 66.02 \\
\hline & Aw (AHP) & 43.87 & 52.78 & 55.41 & 41.90 & 49.92 & 46.55 & 59.07 & 62.39 & 32.49 & 38.59 & 63.14 & 58.92 & 54.10 & 60.81 & 28.86 & 64.42 & 58.91 & 51.95 & 42.22 & 61.56 & 74.42 \\
\hline & OA (WSM) & 37.33 & 60.11 & 71.55 & 31.73 & 54.56 & 40.57 & 78.20 & 81.19 & 16.82 & 21.89 & 78.90 & 77.78 & 59.11 & 79.69 & 16.34 & 81.62 & 73.54 & 58.85 & 29.19 & 79.33 & 87.21 \\
\hline & $\mathrm{OA}(\mathrm{AHP})$ & 58.40 & 59.92 & 72.97 & 36.62 & 66.18 & 43.91 & 87.61 & 50.66 & 27.39 & 40.51 & 71.12 & 83.85 & 83.43 & 76.35 & 24.71 & 71.02 & 84.07 & 72.81 & 41.15 & 55.84 & 82.22 \\
\hline \multirow{9}{*}{ 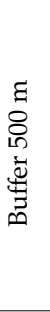 } & NP & 872 & 873 & 875 & 870 & 875 & 873 & 871 & 871 & 870 & 874 & 876 & 875 & 871 & 874 & 873 & 873 & 874 & 875 & 873 & 874 & 871 \\
\hline & Sp (WSM) & 141 & 568 & 570 & 155 & 601 & 115 & 870 & 871 & 0 & 105 & 754 & 873 & 404 & 858 & 13 & 870 & 835 & 462 & 14 & 853 & 871 \\
\hline & $\mathrm{Sp}$ (AHP) & 511 & 551 & 663 & 211 & 731 & 227 & 871 & 332 & 134 & 373 & 666 & 875 & 858 & 723 & 125 & 775 & 871 & 714 & 192 & 500 & 852 \\
\hline & As (WSM) & 16.17 & 65.06 & 65.14 & 17.82 & 68.69 & 13.17 & 99.89 & 100.00 & 0.00 & 12.01 & 86.07 & 99.77 & 46.38 & 98.17 & 1.49 & 99.66 & 95.54 & 52.80 & 1.60 & 97.60 & 100.00 \\
\hline & As (AHP) & 58.60 & 63.12 & 75.77 & 24.25 & 83.54 & 26.00 & 100.00 & 38.12 & 15.40 & 42.68 & 76.03 & 100.00 & 98.51 & 82.72 & 14.32 & 88.77 & 99.66 & 81.60 & 21.99 & 57.21 & 97.82 \\
\hline & Aw (WSM) & 52.62 & 53.00 & 54.60 & 42.11 & 57.33 & 45.48 & 73.95 & 45.92 & 36.05 & 46.72 & 58.20 & 68.01 & 63.45 & 58.02 & 38.18 & 60.80 & 68.96 & 54.48 & 43.01 & 50.29 & 62.44 \\
\hline & $\mathrm{Aw}$ (AHP) & 42.61 & 52.24 & 51.39 & 42.52 & 51.81 & 43.46 & 58.88 & 59.79 & 30.25 & 40.00 & 61.85 & 59.11 & 50.32 & 60.35 & 29.14 & 65.70 & 59.62 & 50.00 & 37.48 & 61.03 & 71.84 \\
\hline & OA (WSM) & 29.39 & 58.65 & 58.27 & 30.17 & 60.25 & 28.32 & 79.38 & 79.90 & 15.12 & 26.01 & 73.96 & 79.44 & 48.35 & 79.26 & 15.31 & 82.68 & 77.58 & 51.40 & 19.54 & 79.31 & 85.92 \\
\hline & $\mathrm{OA}(\mathrm{AHP})$ & 55.61 & 58.06 & 65.19 & 33.18 & 70.43 & 35.74 & 86.97 & 42.02 & 25.72 & 44.70 & 67.11 & 84.00 & 80.98 & 70.37 & 26.25 & 74.79 & 84.31 & 68.04 & 32.50 & 53.75 & 80.13 \\
\hline \multirow{9}{*}{ 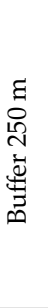 } & NP & 220 & 217 & 219 & 219 & 214 & 220 & 217 & 216 & 219 & 219 & 221 & 216 & 214 & 217 & 219 & 216 & 219 & 218 & 219 & 220 & 217 \\
\hline & Sp (WSM) & 41 & 177 & 86 & 67 & 157 & 7 & 217 & 216 & 0 & 14 & 201 & 216 & 60 & 209 & 0 & 216 & 202 & 110 & 0 & 219 & 217 \\
\hline & Sp (AHP) & 41 & 177 & 86 & 67 & 157 & 7 & 217 & 216 & 0 & 14 & 201 & 216 & 60 & 209 & 0 & 216 & 202 & 110 & 0 & 219 & 217 \\
\hline & As (WSM) & 18.64 & 81.57 & 39.27 & 30.59 & 73.36 & 3.18 & 100.00 & 100.00 & 0.00 & 6.39 & 90.95 & 100.00 & 28.04 & 96.31 & 0.00 & 100.00 & 92.24 & 50.46 & 0.00 & 99.55 & 100.00 \\
\hline & As (AHP) & 18.64 & 81.57 & 39.27 & 30.59 & 73.36 & 3.18 & 100.00 & 100.00 & 0.00 & 6.39 & 90.95 & 100.00 & 28.04 & 96.31 & 0.00 & 100.00 & 92.24 & 50.46 & 0.00 & 99.55 & 100.00 \\
\hline & Aw (WSM) & 43.13 & 53.81 & 47.68 & 46.52 & 52.94 & 41.84 & 58.60 & 59.45 & 30.63 & 38.38 & 58.80 & 59.99 & 48.29 & 57.90 & 30.48 & 66.07 & 59.96 & 49.33 & 34.90 & 61.40 & 69.90 \\
\hline & Aw (AHP) & 43.13 & 53.81 & 47.68 & 46.52 & 52.94 & 41.84 & 58.60 & 59.45 & 30.63 & 38.38 & 58.80 & 59.99 & 48.29 & 57.90 & 30.48 & 66.07 & 59.96 & 50.03 & 34.90 & 61.40 & 69.90 \\
\hline & OA (WSM) & 30.88 & 67.69 & 43.48 & 38.56 & 63.15 & 22.51 & 79.30 & 79.72 & 15.31 & 22.39 & 74.87 & 79.99 & 38.16 & 77.11 & 15.24 & 83.03 & 76.10 & 49.89 & 17.45 & 80.47 & 84.95 \\
\hline & $\mathrm{OA}(\mathrm{AHP})$ & 30.88 & 67.69 & 43.48 & 38.56 & 63.15 & 22.51 & 79.30 & 79.72 & 15.31 & 22.39 & 74.87 & 79.99 & 38.16 & 77.11 & 15.24 & 83.03 & 76.10 & 50.25 & 17.45 & 80.47 & 84.95 \\
\hline$\ddot{g}$ & $\mathrm{OA}(\mathrm{AHP})$ & 48.30 & 61.89 & 60.55 & 36.12 & 66.59 & 34.05 & 84.63 & 57.47 & 22.81 & 35.87 & 71.04 & 82.62 & 67.52 & 74.61 & 22.07 & 76.28 & 81.49 & 63.70 & 30.37 & 63.35 & 82.43 \\
\hline 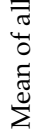 & OA (WSM) & 32.53 & 62.15 & 57.77 & 33.49 & 59.32 & 30.47 & 78.96 & 80.27 & 15.75 & 23.43 & 75.91 & 79.07 & 48.54 & 78.69 & 15.63 & 82.44 & 75.74 & 53.38 & 22.06 & 79.70 & 86.03 \\
\hline
\end{tabular}

Note: $\mathrm{Np}$ is the number of pixels, and the $\mathrm{Sp}$ is the WSM suitable pixels. 


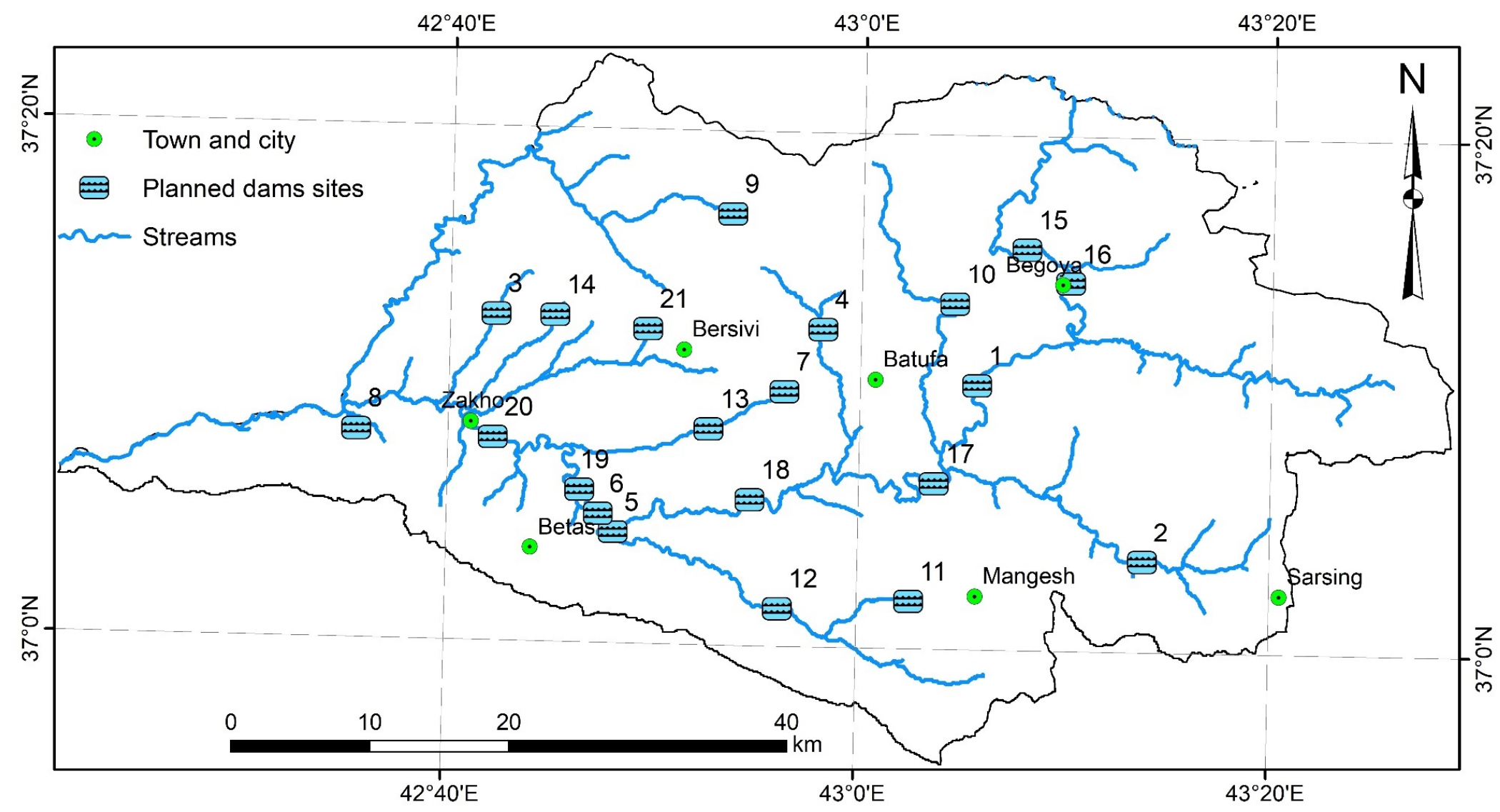

Figure A1. Planned dam sites by the Ministry of Agricultural and Water Resources, Kurdistan Region, Iraq [16]. 

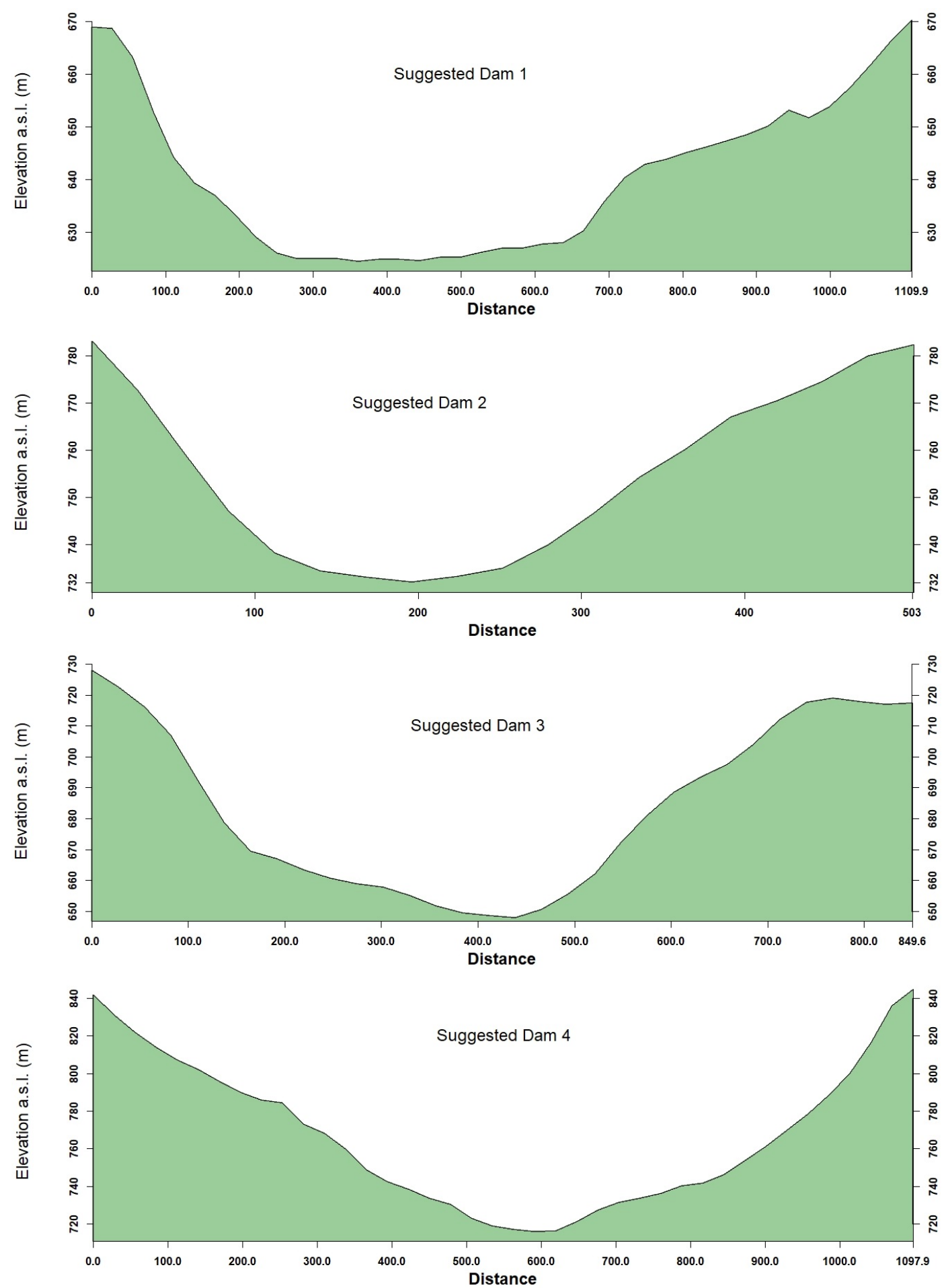

Figure A2. Cont. 

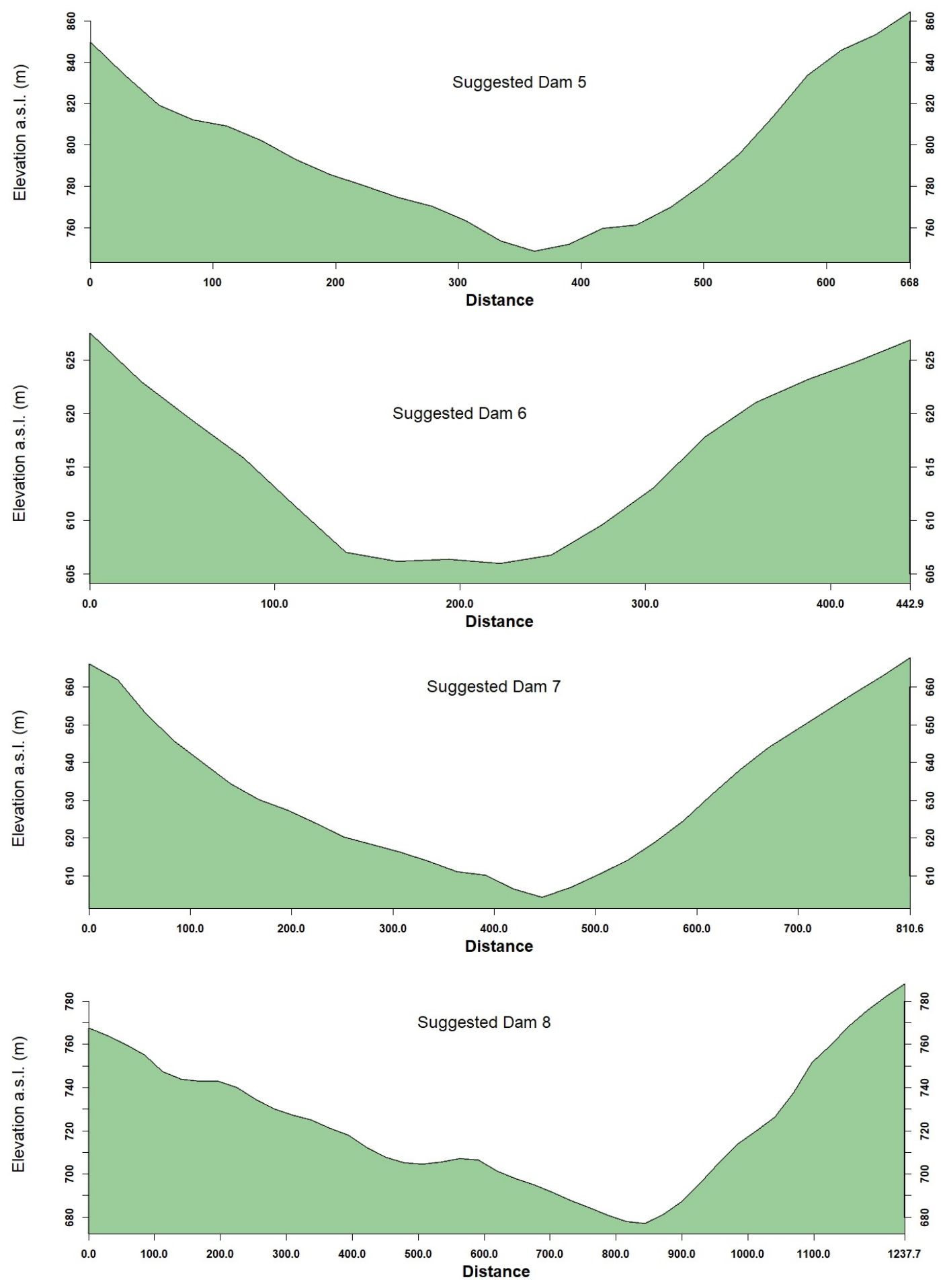

Figure A2. Cont. 

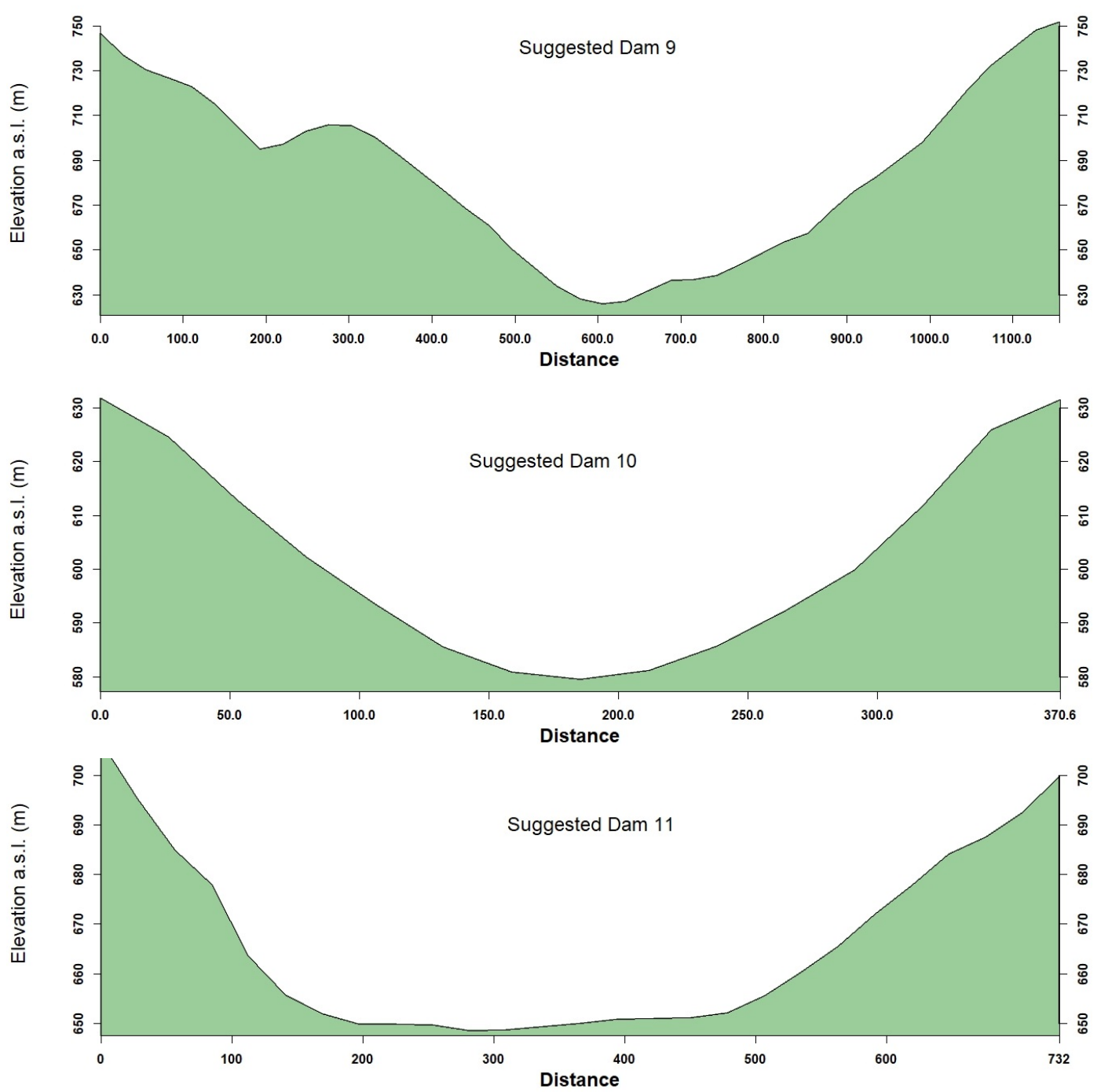

Figure A2. Cross section of the suggested dam sites.

\section{References}

1. UN. World Population Prospects the 2017 Revision; UN: New York, NY, USA, 2017.

2. UN United Nations Decade for Deserts and the Fight against Desertification. Available online: http: //www.un.org/en/events/desertification_decade/whynow.shtml (accessed on 27 February 2020).

3. Jassim, M.D. The Reality and Future of Water Resources in Iraq 2010; Ministry of Water Resources: Baghdad, Iraq, 2010.

4. UNDP. Drought Impact Assessment, Recovery and Mitigation Framework and Regional Project Design in Kurdistan Region (KR); UNDP: New York, NY, USA, 2011.

5. Fard, F.V.; Khosravi, M.; Talebi, M.; Jafarzadeh, F. Evaluating liquefaction potential in an embankment dam foundation using shear wave velocity measurements. In Proceedings of the Annual Conference-Canadian Society for Civil Engineering, Yellowknife, NT, Canada, 6-9 June 2007; Volume 1, pp. 362-369.

6. Gholami, R.; Rasouli, V. Mechanical and elastic properties of transversely isotropic slate. Rock Mech. Rock Eng. 2014, 47, 1763-1773. [CrossRef]

7. Issa, I.E. Sedimentological and Hydrological Investigation of Mosul Dam Reservoir. Ph.D. Thesis, Luleå University of Technology, Luleå, Sweden, 2015.

8. Ibrahim, G.R.F.; Rasul, A.; Hamid, A.A.; Ali, Z.F.; Dewana, A.A. Suitable site selection for rainwater harvesting and storage case study using Dohuk governorate. Water 2019, 11, 864. [CrossRef]

9. Mugo, G.M.; Odera, P.A. Site selection for rainwater harvesting structures in Kiambu County-Kenya. Egypt. J. Remote Sens. Space Sci. 2019, 22, 155-164. [CrossRef] 
10. Akintorinwa, O.J.; Okoro, O.V. Combine electrical resistivity method and multi-criteria GIS-based modeling for landfill site selection in the Southwestern Nigeria. Environ. Earth Sci. 2019, 78, 162. [CrossRef]

11. Saaty, T.L.; Vargas, L.G. Hierarchical analysis of behavior in competition: Prediction in chess. Behav. Sci. 1980, 25, 180-191. [CrossRef]

12. Fishburn, P.C. Additive Utilities with Incomplete Product Set: Applications to Priorities and Assignments. Oper. Res. 1967, 15, 537-542. [CrossRef]

13. Nzotcha, U.; Kenfack, J.; Blanche Manjia, M. Integrated multi-criteria decision making methodology for pumped hydro-energy storage plant site selection from a sustainable development perspective with an application. Renew. Sustain. Energy Rev. 2019, 112, 930-947. [CrossRef]

14. Noori, A.M.; Pradhan, B.; Ajaj, Q.M. Dam site suitability assessment at the Greater Zab River in northern Iraq using remote sensing data and GIS. J. Hydrol. 2019, 574, 964-979. [CrossRef]

15. Naraghi, S.; Masoumi, I.; Rashidinejad, F. Optimization of tailings disposal method using fuzzy analytic hierarchy process. Water Sci. Technol. Water Supply 2019, 19, 1563-1571. [CrossRef]

16. Ministry of Agricultural and Water Resources (MAWR). Dams Master Plan for Kurdistan; Ministry of Agricultural and Water Resources (MAWR): Erbil, Iraq, 2013.

17. Othman, A.A.; Al- Maamar, A.F.; Al-Manmi, D.A.M.; Liesenberg, V.; Hasan, S.; Al-Saady, Y.I.; Shihab, A.T.; Khwedim, K. Application of DInSAR-PSI Technology for Deformation Monitoring of the Mosul Dam, Iraq. Remote Sens. 2019, 11, 2632. [CrossRef]

18. Milillo, P.; Bürgmann, R.; Lundgren, P.; Salzer, J.; Perissin, D.; Fielding, E.; Biondi, F.; Milillo, G. Space geodetic monitoring of engineered structures: The ongoing destabilization of the Mosul dam, Iraq. Sci. Rep. 2016, 6, 37408. [CrossRef] [PubMed]

19. Jha, M.K.; Chowdary, V.M.; Kulkarni, Y.; Mal, B.C. Rainwater harvesting planning using geospatial techniques and multicriteria decision analysis. Resour. Conserv. Recycl. 2014, 83, 96-111. [CrossRef]

20. CityPopulation Iraq: Governorates, Major Cities \& Urban Centers-Population Statistics, Maps, Charts, Weather and Web Information. Available online: http://www.citypopulation.de/Iraq-Cities.html (accessed on 27 February 2020).

21. Fell, R.; MacGregor, P.; Stapledon, D.; Bell, G. Geotechnical Engineering of Dams; CRC Press: Boca Raton, FL, USA, 2005; ISBN 9780415889322.

22. Climate Data; The Agro-Meteorological Department of the General Directorate of Research and Agricultural Extension of the Ministry of Agriculture of the Kurdistan Regional, Kurdistan-Iraq, The Agro-Meteorological Department of the General Directorate of Research and Agricultural Extension of the Ministry of Agriculture of the Kurdistan Regional, Iraq: Kurdistan, Iraq, 2006.

23. Ramakrishnan, D.; Bandyopadhyay, A.; Kusuma, K.N. SCS-CN and GIS-based approach for identifying potential water harvesting sites in the Kali Watershed, Mahi River Basin, India. J. Earth Syst. Sci. 2009, 118, 355-368. [CrossRef]

24. Grum, B.; Hessel, R.; Kessler, A.; Woldearegay, K.; Yazew, E.; Ritsema, C.; Geissen, V. A decision support approach for the selection and implementation of water harvesting techniques in arid and semi-arid regions. Agric. Water Manag. 2016, 173, 35-47. [CrossRef]

25. Tiwari, K.; Goyal, R.; Sarkar, A. GIS-based Methodology for Identification of Suitable Locations for Rainwater Harvesting Structures. Water Resour. Manag. 2018, 32, 1811-1825. [CrossRef]

26. Al-Abadi, A.M.; Shahid, S.; Ghalib, H.B.; Handhal, A.M. A GIS-Based Integrated Fuzzy Logic and Analytic Hierarchy Process Model for Assessing Water-Harvesting Zones in Northeastern Maysan Governorate, Iraq. Arab. J. Sci. Eng. 2017, 42, 2487-2499. [CrossRef]

27. Rejani, R.; Rao, K.V.; Rao, C.H.S.; Osman, M.; Reddy, K.S.; George, B. Identification Of Potential Rainwater-Harvesting Sites For The Sustainable Management Of A Semi-Arid Watershed. Irrig. Drain. 2017, 66, 227-237. [CrossRef]

28. Mahmoud, S.H.; Tang, X. Monitoring prospective sites for rainwater harvesting and stormwater management in the United Kingdom using a GIS-based decision support system. Environ. Earth Sci. 2015, 73, 8621-8638. [CrossRef]

29. Sayl, K.N.; Muhammad, N.S.; El-Shafie, A. Robust approach for optimal positioning and ranking potential rainwater harvesting structure (RWH): A case study of Iraq. Arab. J. Geosci. 2017, 10, 413. [CrossRef] 
30. Singhai, A.; Das, S.; Kadam, A.K.; Shukla, J.P.; Bundela, D.S.; Kalashetty, M. GIS-based multi-criteria approach for identification of rainwater harvesting zones in upper Betwa sub-basin of Madhya Pradesh, India. Environ. Dev. Sustain. 2019, 21,777-797. [CrossRef]

31. Al-Ruzouq, R.; Shanableh, A.; Yilmaz, A.G.; Idris, A.; Mukherjee, S.; Khalil, M.A.; Gibril, M.B. Dam Site Suitability Mapping and Analysis Using an Integrated GIS and Machine Learning Approach. Water 2019, 11, 1880. [CrossRef]

32. Jenks, G.F. The Data Model Concept in Statistical Mapping. Int. Yearb. Cartogr. 1967, 7, 186-190.

33. Othman, A.A.; Gloaguen, R.; Andreani, L.; Rahnama, M. Improving landslide susceptibility mapping using morphometric features in the Mawat area, Kurdistan Region, NE Iraq: Comparison of different statistical models. Geomorphology 2018, 319, 147-160. [CrossRef]

34. Mulliner, E.; Malys, N.; Maliene, V. Comparative analysis of MCDM methods for the assessment of sustainable housing affordability. Omega (United Kingdom) 2016, 59, 146-156. [CrossRef]

35. Guitouni, A.; Martel, J.-M. Tentative guidelines to help choosing an appropriate MCDA method. Eur. J. Oper. Res. 1998, 109, 501-521. [CrossRef]

36. Roy, B.; Słowiński, R. Questions guiding the choice of a multicriteria decision aiding method. EURO J. Decis. Process. 2013, 1, 69-97. [CrossRef]

37. Triantaphyllou, E. Multi-criteria Decision Making Methods: A Comparative Study; Applied Optimization; Springer: New York, NY, USA, 2000; ISBN 9780792366072.

38. Hwang, C.L.; Yoon, K. Multiple Attribute Decision Making: Methods and Applications A State-of-the-Art Survey; Lecture Notes in Economics and Mathematical Systems; Springer: Berlin/Heidelberg, Germany, 2012; ISBN 9783642483189.

39. Miller, D.W.; Starr, M.K. Executive Decisions and Operations Research; Prentice-Hall international series in management; Prentice-Hall: Upper Saddle River, NJ, USA, 1969.

40. Damasceno Pavani, I.; Ennes Cicerelli, R.; de Almeida, T.; Zandonadi Moura, L.; Contreras, F. Allocation of sanitary landfill in consortium: Strategy for the Brazilian municipalities in the State of Amazonas. Environ. Monit. Assess. 2019, 191. [CrossRef]

41. Ekmekçioĝlu, M.; Kaya, T.; Kahraman, C. Fuzzy multicriteria disposal method and site selection for municipal solid waste. Waste Manag. 2010, 30, 1729-1736. [CrossRef]

42. Coban, A.; Ertis, I.F.; Cavdaroglu, N.A. Municipal solid waste management via multi-criteria decision making methods: A case study in Istanbul, Turkey. J. Clean. Prod. 2018, 180, 159-167. [CrossRef]

43. Bah, Y.; Tsiko, R.G. Landfill site selection by integrating geographical information systems and multi-criteria decision analysis: A case study of Freetown, Sierra Leone. African Geogr. Rev. 2011, 30, 67-99. [CrossRef]

44. Shahabi, H.; Keihanfard, S.; Ahmad, B.B.; Amiri, M.J.T. Evaluating Boolean, AHP and WLC methods for the selection of waste landfill sites using GIS and satellite images. Environ. Earth Sci. 2014, 71, 4221-4233. [CrossRef]

45. Cheng, S.; Chan, C.W.; Huang, G.H. Using multiple criteria decision analysis for supporting decisions of solid waste management. J. Environ. Sci. Heal. - Part A Toxic/Hazardous Subst. Environ. Eng. 2002, 37, 975-990. [CrossRef] [PubMed]

46. Bellehumeur, C.; Vasseur, L.; Ansseau, C.; Marcos, B. Implementation of a multicriteria sewage sludge management model in the southern Quebec municipality of Lac-Megantic, Canada. J. Environ. Manage. 1997, 50, 51-66. [CrossRef]

47. Saaty, T.L. The Analytic Hierarchy Process in Conflict Management. Int. J. Confl. Manag. 1990, 1, 47-68. [CrossRef]

48. Zhang, L.; Lavagnolo, M.C.; Bai, H.; Pivato, A.; Raga, R.; Yue, D. Environmental and economic assessment of leachate concentrate treatment technologies using analytic hierarchy process. Resour. Conserv. Recycl. 2019, 474-480. [CrossRef]

49. Salar, S.G.; Othman, A.A.; Hasan, S.E. Identification of suitable sites for groundwater recharge in Awaspi watershed using GIS and remote sensing techniques. Environ. Earth Sci. 2018, 77. [CrossRef]

50. Clinton, N.; Holt, A.; Scarborough, J.; Yan, L.I.; Gong, P. Accuracy assessment measures for object-based image segmentation goodness. Photogramm. Eng. Remote Sens. 2010, 76, 289-299. [CrossRef]

51. Ayalew, L.; Yamagishi, H. The application of GIS-based logistic regression for landslide susceptibility mapping in the Kakuda-Yahiko Mountains, Central Japan. Geomorphology 2005, 65, 15-31. [CrossRef] 
52. Sissakian, V.K. Geological Report on Al-Mosul Quadrangle, Sheet No. NJ-38-03, Scale 1:250 000; Iraq Geological Survey: Baghdad, Iraq, 1995.

53. Al-Mousawi, H.A.; Sissakian, V.K.; Fouad, S.F.; Survey, I.G. The Geology of ZakhoQuadrangle, Scale 1:250000; Iraq Geological Survey: Baghdad, Iraq, 2008.

54. Foad, S. Tectonic Map of Iraq, Scale 1:1,000,000; Iraq Geological Survey: Baghdad, Iraq, 2012.

55. Alavi, M. Structures of the Zagros fold-thrust belt in Iran. Am. J. Sci. 2007, 307, 1064-1095. [CrossRef]

56. Obaid, A.K.; Allen, M.B. Landscape maturity, fold growth sequence and structural style in the Kirkuk Embayment of the Zagros, northern Iraq. Tectonophysics 2017, 717, 27-40. [CrossRef]

57. Obaid, A.K.; Allen, M.B. Landscape expressions of tectonics in the Zagros fold-and-thrust belt. Tectonophysics 2019, 766, 20-30. [CrossRef]

58. Othman, A.A.; Gloaguen, R. River Courses Affected by Landslides and Implications for Hazard Assessment: A High Resolution Remote Sensing Case Study in NE Iraq-W Iran. Remote Sens. 2013, 5, 1024-1044. [CrossRef]

59. Othman, A.A.; Gloaguen, R. Automatic extraction and size distribution of landslides in kurdistan region, NE Iraq. Remote Sens. 2013, 5, 2389-2410. [CrossRef]

60. De Vera, J.; Gines, J. Structure of the Zagros fold and thrust belt in the Kurdistan Region, northern Iraq. Trabajos de Geología 2009, 217, 213-217.

61. Forzieri, G.; Gardenti, M.; Caparrini, F.; Castelli, F. A methodology for the pre-selection of suitable sites for surface and underground small dams in arid areas: A case study in the region of Kidal, Mali. Phys. Chem. Earth Parts A/B/C 2008, 33, 74-85. [CrossRef]

62. Javhar, A.; Chen, X.; Bao, A.; Jamshed, A.; Yunus, M.; Jovid, A.; Latipa, T. Comparison of multi-resolution optical Landsat-8, Sentinel-2 and radar Sentinel-1 data for automatic lineament extraction: A case study of Alichur area, SE Pamir. Remote Sens. 2019, 11. [CrossRef]

63. ESRI. ArcGIS Desktop: Release 10 2011. Available online: https://desktop.arcgis.com/en/ (accessed on 27 February 2020).

64. EROS Landsat OLI. Available online: https://earthexplorer.usgs.gov/ (accessed on 27 February 2020).

65. Geomatica, P. PCI Geomatica 2016. Available online: https://www.pcigeomatics.com/ (accessed on 27 February 2020).

66. Nachtergaele, F.; van Velthuizen, H.; van Engelen, V.; Fischer, G.; Jones, A.; Montanarella, L.; Petri, M.; Prieler, S.; Teixeira, E.; Shi, X. Harmonized World Soil Database (Version 1.2); ORNL DAAC: Oak Ridge, TN, USA, 2012; pp. 1-50. Available online: http://daac.ornl.gov/cgi-bin/dsviewer.pl?ds_id=1247 (accessed on 27 February 2020).

67. Adham, A.; Riksen, M.; Ouessar, M.; Abed, R.; Ritsema, C. Development of Methodology for Existing Rainwater Harvesting Assessment in (semi-)Arid Regions BT. In Water and Land Security in Drylands: Response to Climate Change; Ouessar, M., Gabriels, D., Tsunekawa, A., Evett, S., Eds.; Springer International Publishing: Cham, Switzerland, 2017; pp. 171-184. ISBN 978-3-319-54021-4.

68. Kahinda, J.M.; Lillie, E.S.B.; Taigbenu, A.E.; Taute, M.; Boroto, R.J. Developing suitability maps for rainwater harvesting in South Africa. Phys. Chem. Earth Parts A/B/C 2008, 33, 788-799. [CrossRef]

69. Mbilinyi, B.P.; Tumbo, S.D.; Mahoo, H.F.; Mkiramwinyi, F.O. GIS-based decision support system for identifying potential sites for rainwater harvesting. Phys. Chem. Earth Parts A/B/C 2007, 32, 1074-1081. [CrossRef]

70. USDA. Soil Mechanics Level 1, Module 3. USDA Textural Classification Study Guide; USDA: Washington, DC, USA, 1987.

71. Vapnik, V.N. The Nature of Statistical Learning Theory, 2nd ed.; Springer: New York, NY, USA, 1999.

72. Othman, A.A.; Gloaguen, R. Improving lithological mapping by SVM classification of spectral and morphological features: The discovery of a new chromite body in the Mawat ophiolite complex (Kurdistan, NE Iraq). Remote Sens. 2014, 6, 6867-6896. [CrossRef]

73. Yang, X. Parameterizing support vector machines for land cover classification. Photogramm. Eng. Remote Sens. 2011, 77, 27-38. [CrossRef]

74. Othman, A.; Al-Saady, Y.; Al-Khafaji, A.; Gloaguen, R. Environmental change detection in the central part of Iraq using remote sensing data and GIS. Arab. J. Geosci. 2014, 7, 1017-1028. [CrossRef]

75. Congalton, R.G. A review of assessing the accuracy of classifications of remotely sensed data. Remote Sens. Environ. 1991, 37, 35-46. [CrossRef] 
76. Cohen, J. A coefficient of agreement of nominal scales. Psychol. Meas. 1960, 2, 37-46. [CrossRef]

77. Charnpratheep, K.; Zhou, Q.; Garner, B. Preliminary landfill site screening using fuzzy geographical information systems. Waste Manag. Res. 1997, 15, 197-215. [CrossRef]

78. Demesouka, O.E.; Vavatsikos, A.P.; Anagnostopoulos, K.P. GIS-based multicriteria municipal solid waste landfill suitability analysis: A review of the methodologies performed and criteria implemented. Waste Manag. Res. 2014, 32, 270-296. [CrossRef]

79. Buraihi, F.H.; Shariff, A.R.M. Selection of rainwater harvesting sites by using remote sensing and GIS techniques: A case study of Kirkuk, Iraq. J. Teknol. 2015, 76, 75-81. [CrossRef]

80. Hamzeh, M.; Ali Abbaspour, R.; Davalou, R. Raster-based outranking method: A new approach for municipal solid waste landfill (MSW) siting. Environ. Sci. Pollut. Res. 2015, 22, 12511-12524. [CrossRef]

81. GSFC_DAAC Tropical Rainfall Measurement Mission Project (TRMM;3B43 V7). Available online: http: //disc.gsfc.nasa.gov/datacollection/TRMM_3B42_daily_V6.shtml (accessed on 27 February 2020).

82. Kummerow, C.; Barnes, W.; Kozu, T.; Shiue, J.; Simpson, J. The Tropical Rainfall Measuring Mission (TRMM) sensor package. J. Atmos. Ocean. Technol. 1998, 15, 809-817. [CrossRef]

83. Yousuf, M.A.; Rapantova, N.; Younis, J.H. Sustainable water management in Iraq (Kurdistan) as a challenge for governmental responsibility. Water 2018, 10, 1651. [CrossRef]

84. Deus, D.; Gloaguen, R. Remote Sensing Analysis of Lake Dynamics in Semi-Arid Regions: Implication for Water Resource Management. Lake Manyara, East African Rift, Northern Tanzania. Water 2013, 5, 698-727. [CrossRef]

85. Andreani, L.; Gloaguen, R.; Shahzad, F. A new set of MATLAB functions (TecDEM toolbox) to analyze erosional stages in landscapes and base-level changes in river profiles. Geophys. Res. Abstr. 2014, 16. Available online: https://ui.adsabs.harvard.edu/abs/2014EGUGA..1616682A/abstract (accessed on 27 February 2020).

86. Shahzad, F.; Gloaguen, R. TecDEM: A MATLAB based toolbox for tectonic geomorphology, Part 2: Surface dynamics and basin analysis. Comput. Geosci. 2011, 37, 261-271. [CrossRef]

87. Shahzad, F.; Gloaguen, R. TecDEM: A MATLAB based toolbox for tectonic geomorphology, Part 1: Drainage network preprocessing and stream profile analysis. Comput. Geosci. 2011, 37, 250-260. [CrossRef]

88. Banasik, K.; Rutkowska, A.; Kohnová, S. Retention and curve number variability in a small agricultural catchment: The probabilistic approach. Water 2014, 6, 1118-1133. [CrossRef]

89. Hawkins, R.H.; Hjelmfelt, A.T., Jr.; Zevenbergen, A.W. Runoff probability, storm depth, and curve numbers. J. Irrig. Drain. Eng. 1985, 111, 330-340. [CrossRef]

90. Ponce, V.M.; Hawkins, R.H. Runoff curve number: Has it reached maturity? J. Hydrol. Eng. 1996, 1, 11-18. [CrossRef]

91. Norouzi, A.; Habibi, H.; Nazari, B.; Noh, S.J.; Seo, D.-J.; Zhang, Y. Toward parsimonious modeling of frequency of areal runoff from heavy-to-extreme precipitation in large urban areas under changing conditions: A derived moment approach. Stoch. Environ. Res. Risk Assess. 2019, 33, 1263-1281. [CrossRef]

92. Fleming, M.J.; Doan, J.H. HEC-GeoHMS; Davis, CA, USA, 2013. Available online: https://www.hec.usace. army.mil/software/hec-geohms/ (accessed on 27 February 2020).

93. Singh, P.K.; Mishra, S.K.; Berndtsson, R.; Jain, M.K.; Pandey, R.P. Development of a Modified SMA Based MSCS-CN Model for Runoff Estimation. Water Resour. Manag. 2015, 29, 4111-4127. [CrossRef]

94. Rolland, A.; Rangarajan, R. Runoff estimation and potential recharge site delineation using analytic hierarchy process. Geocarto Int. 2013, 28, 159-170. [CrossRef]

95. OCHA-IRAQ Iraq—Datasets. 2018. Available online: https://www.unocha.org/iraq (accessed on 27 February 2020).

96. Jamali, A.A.; Randhir, T.O.; Nosrati, J. Site suitability analysis for subsurface dams using Boolean and fuzzy logic in arid watersheds. J. Water Resour. Plan. Manag. 2018, 144. [CrossRef]

97. Shaw, E.M.; Beven, K.J.; Chappell, N.A.; Lamb, R. Hydrology in Practice, 4th ed.; Taylor \& Francis: Abington, Thames, UK, 2010; ISBN 9780203030233.

98. Jozaghi, A.; Alizadeh, B.; Hatami, M.; Flood, I.; Khorrami, M.; Khodaei, N.; Tousi, E.G. A comparative study of the AHP and TOPSIS techniques for dam site selection using GIS: A case study of Sistan and Baluchestan Province, Iran. Geosciences 2018, 8, 494. [CrossRef] 
99. Noori, A.; Bonakdari, H.; Morovati, K.; Gharabaghi, B. The optimal dam site selection using a group decision-making method through fuzzy TOPSIS model. Environ. Syst. Decis. 2018, 38, 471-488. [CrossRef]

100. Tscheikner-Gratl, F.; Egger, P.; Rauch, W.; Kleidorfer, M. Comparison of multi-criteria decision support methods for integrated rehabilitation prioritization. Water 2017, 9, 68. [CrossRef]

101. Adamczak, M.; Domanski, R.; Cyplik, P.; Malinowska, K. The identification of the influence of transforming multiple-criteria decisionmaking method parameters on their efficiency-Simulation study results. IFAC-PapersOnLine 2017, 50, 3505-3510. [CrossRef]

(C) 2020 by the authors. Licensee MDPI, Basel, Switzerland. This article is an open access article distributed under the terms and conditions of the Creative Commons Attribution (CC BY) license (http://creativecommons.org/licenses/by/4.0/). 